\title{
Of Econometrics and Indeterminacy: A Study of Investors' Reactions to "Changes" in Corporate Law
}

\author{
Elliott J. Weiss $\dagger$ \\ Lawrence J. White
}

\section{INTRODUCTION}

Is the inarket sensitive to changes in corporate law? If it is, what kinds of changes lead to market reactions? In a legal systein where states charter corporations and where the corporate law of the chartering state regulates the relationship between a corporation's shareholders and its managers, the answers to these questions should influence one's approach both to particular doctrinal issues and to questions concerning how and by whoin corporate law should be inade.

Few dispute that corporate laws in general, and corporate governance rules in particular, should subject inanagers to a set of constraints designed to enhance the efficiency of corporate operations. ${ }^{1}$ However, there is considerable disagreement about what particular constraints, or systems of constraints, best proinote this objective. In recent years, those debating this issue generally have pursued one of two lines of arguinent.

One group of commentators has tended to criticize actions by state

$\dagger$ Professor of Law, Benjamin N. Cardozo School of Law, Yeshiva University. B.A. 1961, Dartmouth College; LL.B. 1964, Yale Law School.

$\ddagger$ Professor of Economics, New York University Graduate School of Business Administration. B.A. 1964, Harvard University; M.S. 1965, London School of Economics; Ph.D. 1969, Harvard University.

We would like to thank William Bratton, Charles Yablon, Anthony D'Amato, Roberta Romano, Merritt Fox, and participants in faculty workshops at Cardozo, Columbia, and Yale Law Schools for helpful comments. Linda Canina and Dana Shanler provided valuable research assistance.

1. The authority of managers-a term we use to refer collectively to directors, executives, and controlling shareholders-is limited by legal constraints, in the nature of rules, and by equitable constraints, in the nature of standards. Legal constraints generally are procedural and statutory; they relate largely to the circumstances in which shareholders and their elected representatives, a corporation's directors, are required or allowed to play a role in corporate decisionmaking. Equitable constraints relate largely to the circumstances in which a court, acting at a shareholder's behest, will intervene in or review the substance of managers' decisions that at least arguably have been made in accordance with all relevant legal requirements. In practice, all state systems of corporate law involve a mix of legal and equitable constraints, and all limit the application of those constraints so that managers can make most corporate decisions free of any threat of direct shareholder involvement in the decisionmaking process. 
courts and state legislatures that reduce the constraints under which corporate managers operate. These commentators generally have supported votimg requirements that allow shareholders to participate more extensively in corporate decisionmaking, ${ }^{2}$ arguing that such requirements better protect shareholders and further legitimate managers' decisions. These commentators also have applauded courts that have been willing to scrutimize closely the substance of major corporate transactions. The possibihity of such judicial review, they claim, deters managers from actmg without sufficient care, from enriching themselves at the expense of their companies, and from structuring transactions in a fashion that subverts shareholders' voting rights. ${ }^{3}$ These commentators recognize that a system that imposes more stringent legal and equitable constraints on managers' authority may add to the cost of corporate operations, but they beheve that the benefits produced by such constraints far outweigh their costs. ${ }^{4}$

Other commentators value constranits less and markets more. These commentators, who emphasize the agency cost aspects of corporate structure, assert that efficient corporate operations best can be promoted by allowing investors and managers to define by "contract" the rights of shareholders to participate in firm governance and to question managerial decisions. Investors, the agency-cost theorists argue, may well decide that they can influence managers' decisionmaking more effectively, and thus: better protect their investinents, by their actual or potential decisions to buy or sell a coinpany's stock rather than by voting at shareholders' 1neetings or mounting lawsuits challenging managers' decisions. ${ }^{5}$ They further contend that courts that allow shareholders to challenge on equitable grounds otherwise legal corporate transactions may be doing inore harm than good. Their argument is that shareholders may initiate lawsuits challenging corporate transactions primarily to obtain personal financial benefits for theinselves or their attorneys. Consequently, courts' willingness to entertain such lawsuits inay operate largely to benefit these hitigious shareholders at the expense of shareholders as a group.

2. See, e.g., Brudney, Corporate Governance, Agency Costs, and the Rhetoric of Contract, 85 Colum. L. REV. 1403 (1985); Buxbaum, Corporate Legitimacy, Economic Theory, and Legal Doctrine, 45 OнIо ST. L.J. 515 (1984); Cary, Federalism and Corporate Law: Reflections Upon Delaware, 83 YALE L.J. 663, 669 (1974).

3. Brudney, supra note 2, at 1436; Cary, supra note 2, at 692-96.

4. Brudney, supra note 2 , at 1438-39 \& nn.89-91.

5. These analysts characterize managers as "agents" for the shareholders, view corporations as a "nexus of contracts," and see the task of corporate law as one of implementing the contracts upon which shareholders and managers have, explicitly or implicitly, agreed so that shareholders can reduce "agency costs" to an optimal level. See, e.g., Jensen \& Meckling, Theory of the Firm: Managerial Behavior, Agency Costs and Ownership Structure, 3 J. FiN. EcoN. 305, 308-11 (1976). For an analysis of the role of shareholder voting by two such analysts, see Easterbrook \& Fischel, Voting in Corporate Law, 26 J.L. \& ECoN. 395 (1983). 
Several studies have attempted to evaluate these competing lines of argument empirically by analyzing either comparies' decisions to incorporate or reincorporate in a given state, or investors' reactions to those decisions. ${ }^{6}$ By and large, these studies have produced inconclusive results.

We undertook to evaluate these competing lines of argument in a different fashion, by measuring investors' reactions to seven major Delaware court decisions, all of which appeared to make significant, unanticipated changes in Delaware corporate law. ${ }^{7}$ Commentators who prefer to rely on markets to shape the development of corporate law have suggested, both generally and exphitily, that investors would react either positively or negatively to most, and perhaps all, of those seven decisions. ${ }^{8}$ This expectation is consistent with the efficient capital markets hypothesis (ECMH), which holds that stock prices reflect prompt, unbiased evaluations of all pubhicly available information.9 However, we found no statistically significant market reaction to any of the seven decisions.

The absence of significant market reactions was surprising, but far from uninteresting. Retaining our belief that investors, as embodied im "the market," generally understand-often with extraordinary sophistication-the significance of events that have the potential to affect the value of corporate stock, we proceeded to reexainine the other premises on which we had based our study. Ultimately, we identified four possible explanations for the market reactions we found. All four are inconsistent both with the assumptions that would lead one to expect significant market reactions to the seven decisions and with one or more of the claims made by the agency-cost theorists. Specifically, the four explanations all either call into question the existence of a "market for corporate law" or

6. See infra text accompanying notes 30-60.

7. For a discussion of the seven decisions and descriptions of how they seemed to depart from earlier Delaware decisions dealing with the same legal issues, see infra notes 66-145 and accompanying text.

8. See infra text accompanying notes 17-29.

9. J. LoRie, P. Dodd \& M. KimPToN, The STOCK MARKeT: TheORIES AND Evidence 5579 (2d ed. 1985); Fama, Efficient Capital Markets: A Review of Theory and Empirical Work, $25 \mathrm{~J}$. FIN. 383 (1970). The claim that market prices are the best unbiased indicators of the significance of information means only that, with respect to any given information, the reaction of the market, as embodied in securities prices, is more likely to refiect accurately the economic significance of the information than is the reaction of any other identifiable institution or individual. Ronald Gilson and Reinier Kraakman explain how market participants deal with information and why the market's reactions to new information are "unbiased" or efficient. See Gilson \& Kraakman, The Mechanisms of Market Efficiency, 70 VA. L. REV. 549, 568-88 (1984). We prefer the term "unbiased" because "efficient" can be understood to refer either to the reliability of the market's reactions to information or to the accuracy, in relation to notions of inherent or intrinsic value, of the prices established by market transactions. See Wang, Some Arguments That the Stock Market Is Not Efficient, 19 U.C. DAvis L. REV. 341, 344-49 (1986). 
raise doubts about whether courts' decisions in cases involving corporate governance issues are susceptible to the sort of cost-benefit analysis that would allow investors to predict with some confidence that such decisions will either advance or injure shareholders' interests generally. ${ }^{10}$ The most powerful of the four explanations-that the Delaware courts decide corporate governance cases using a set of standards too malleable to provide a secure basis for predicting the outcome of non-identical future cases-also is difficult to reconcile with the concept, currently being used by many market-oriented commentators, that corporate governance issues should be discussed as if corporations represent only a "nexus of contracts" between shareholders and managers.

We return to these points in Parts III and IV, in which we analyze our research results and elaborate on their imphications. In Part I we discuss a series of studies, antecedent to this one, relating to the dynamics of the mcorporation process and the manner in which market forces regulate managers' behavior. In Part II we describe the assumptions that underhie our empirical research, our selection of the seven decisions we studied, our research methodology, and our results.

\section{I}

STUDIES CONCERNING THE "MARKET FOR CORPORATE LAW"

\section{A. The Cary-Winter Debate}

Two articles published in the mid-1970's presented competing descriptions of the incorporation process and the state of Delaware's role therem. Both articles had a common starting point: Delaware is the most popular state of incorporation for publicly-held American corporations. However, the articles offered different explanations for this fact. Those explanations differed in large part because each commentator held different conceptions of how investors influence the development of state corporate laws.

William Cary mitiated the debate, asserting that Delaware had attained its predominant position by pandering to the selfish interests of corporate managers while disregarding the interests of corporate shareholders. ${ }^{11}$ Cary's "shareholder exploitation thesis" ran roughly as follows: (1) Firms are largely free, in a legal sense, to incorporate in any state they wish and to have the corporate laws of that state govern their internal affairs-that is, the relationship between their managers and their shareholders; (2) A firm's managers, not its shareholders, generally

10. That is, as opposed to being beneficial or detrimental to the specific interests of the shareholders of the company or companies involved in the court's decision.

11. Cary, supra note 2 , at $663-84$. 
decide in what state the firm should be incorporated or reincorporated; (3) All other things being equal, inanagers prefer to incorporate in a state whose corporate laws least constrain their authority to structure the firm as they wish and to use corporate resources in whatever fashion they deein appropriate; (4) Early in the twentieth century, Delaware's legislature took the lead in reducing the legal constraints on corporate managers, and Delaware's courts supported the legislature's efforts by exhibiting a marked reluctance to question on equitable grounds transactions that complied with the relevant statutory requirements; and (5) Corporate inanagers found Delaware's approach to corporate law so attractive that other states were forced to coinpete with Delaware im a "race for the bottom"-an effort to develop state systems of corporate law that inanagers find attractive but that, in general, do not adequately protect shareholders' interests. ${ }^{12}$

Cary's article was ambiguous on one important point: It left unclear whether Cary then beheved that Delaware law permitted more exploitation of shareholders' interests than did the laws of other states, or whether he believed instead that competition among the states had driven out "good" state corporate laws to the point that the differences between Delaware and other states were more or less inconsequential. ${ }^{13}$ In either case, it seems clear that Cary beheved investors are unlikely to expend time, money, or energy on attempts to change any one state's corporation laws, since managers would remain free to react to successful reform efforts by reincorporating in other states with more permissive laws. ${ }^{14}$ Rather, investors concerned about the possibility that they might be exploited will react by investing less in corporate equities. ${ }^{15}$ Society thus pays a price for the "race for the bottom" in the form of a lowerthan-optimal level of investment in corporate equities. ${ }^{16}$

12. Id.

13. Cary argued that Delaware's legislature had pandered to managers' selfish interests and that other states' legislatures "try to emulate Delaware by revising their acts along similar lines. Only two or three jurisdictions have resisted this temptation at all." Id. at 666 (footnote omitted). He also stated that "Delaware understandably does not wish to surrender its lead" and, having amended its laws in 1969, 1970, and 1971, was "setting the pace." Id. at 668. These statements suggested that few differences existed between Delaware's corporate statute and the corporate statutes of other states, but that Delaware, because of its responsiveness to managers' desires, occasionally might be able to gain short-term "advantages" in the competition for corporate chartering business. As concerns judge-made aspects of corporate law, Cary compared Delaware court decisions to federal court deeisions, not to the decisions of other state courts. Id. at $670-84$, 692-96.

14. In support of Cary's argument, one might add that rarely would an investor's stake in a firm be large enough to make such a political effort attractive.

15. See Cary, supra note 2, at 671. Other commentators who share Cary's point of view have questioned whether investors are capable of appreciating the exploitation potential of different principles of corporate law. See, e.g., Brudney, supra note 2, at 1411-20.

16. To deal with the "race to the bottom," Cary recommended the enactment of minimum 
Ralph Winter responded with a strikingly different analysis of the dynainics of the inarket for corporate charters, one that emphasized investors' ability to exert a decisive if indirect influence on corporate chartering decisions. ${ }^{17}$ Winter directed his analysis to the situation (which he treated as postulated by Cary's article) in which Delaware law allows managers systeinatically to exploit shareholders while the corporate laws of other states do not allow as inuch exploitation. In such a situation, Winter pointed out, shareholders in Delaware companies would earn lower returns than would shareholders in companies chartered in those other states.

The studies on which the ECMH is based dennonstrate that investors rapidly become aware of and act on publicly available information that has significant inplications for the profitability of their investments. ${ }^{18}$ Relying on this hiterature, Winter argued that investors could be expected to learn of the inferior returns available on investments in Delaware coinpames. Armed with that information, investors would react by paying less for the stock of Delaware companies than for the stock of coinparable coinpanies domiciled in jurisdictions whose laws better protect shareholders' interests. Delaware coinpanies' higher costs of capital would inake it difficult for then to coinpete effectively in product inarkets.

Managers of Delaware companies thus would face serious problems. Delaware coinpanies would be at a disadvantage in the product markets because they would have a higher cost of capital and their managers would be threatened with takeover bids by persons who could increase profitability simiply by reincorporating in other states. ${ }^{19}$ To avoid these probleins, inanagers would be forced to forego any personal advantages they night obtain by incorporating their firms in Delaware. Far fronı being the inost popular donicile for publicly-held conipanies, Delaware would be the least popular. The failure of such a trend to develop, Winter concluded, "strongly suggests that investors . . . believe that they do better under Delaware law than under the laws of the other states."20

federal standards that would be applicable to all publicly-held corporations. Cary, supra note 2, at 701-03.

17. Winter, State Law, Shareholder Protection, and the Theory of the Corporation, 6 J. LEGAL STUD. 251 (1977). Winter did not disagree with Cary's characterization of managers' motivations or of managers' ability to control where firms are chartered.

18. See supra note 9.

19. Winter, supra note 17 , at 256 .

20. Id. at 258. The similarities and differences underlying Cary's and Winter's arguments are worth noting. Neither assumes that investors are wholly uninformed and passive- that is, that investors are "widows and orphans" who routinely are exploited by managers and who either are not aware of this exploitation or cannot learn from it. Rather, both believe that investors learn and react. But Cary believes they react by exiting the world of equities, in whole or in part, either because similar state laws offer them no real choice or because (although they can recognize that 
A number of agency-cost theorists, building on Winter's thesis, have argued that all corporate governance rules should be analyzed as components of a system-or a comprehensive contract-that governs shareholder-manager relationships. This contract-oriented approach has led these theorists to focus on the systematic impact of particular corporate governance rules-that is, how any given rule affects shareholders' interests generally-rather than on whether the rule led to a "fair" result in the case the court was deciding. ${ }^{21}$

Frank Easterbrook and Damel Fischel, for instance, suggest that courts treat as improper all management actions taken in response to hostile takeover bids, even actions that serve ouly to assure that a company's shareholders will receive a higher price for their shares. ${ }^{22}$ Easterbrook and Fischel acknowledge that their proposed rule will deprive some shareholders of preimums they otherwise would receive, but assert that their approach, which relies heavily on analysis of the systematic effects of corporate governance rules, will benefit shareholders as a class. They postulate that if all defensive tactics are prohibited, "acquisition-minded" compamies will search more actively for attractive takeover targets, and managers of all companies will seek more diligently to advance shareholders' imterests in order to avoid being ousted by takeover bids. ${ }^{23}$

Easterbrook, Fischel, and like-minded commentators base their arguments on a rather formalistic view of law. In order to argue that

they are being exploited) they do not have sufficient incentive or expertise to distinguish adequately among the various favorable and unfavorable jurisdictions. By contrast, Winter assumes that investors can distinguish among jurisdictions, that state laws do offer choices, and that investors will exit Delaware companies in favor of companies incorporated elsewhere if Delaware law permits excessive managerial exploitation and the managers of Delaware take advantage of this opportunity. In Winter's world, this ability of investors to move among companies creates a competition among managers for investors' favor which, in turn, prevents managers from seeking out jurisdictions whose laws provide them with incremental opportunities for self-aggrandizement.

21. See, e.g., Easterbrook \& Fischel, The Proper Role of a Target's Management in Responding to a Tender Offer, 94 HaRv. L. REv. 1161 (1981).

22. Id. at 1164 .

23. Id. at 1174-80. One key component to the arguments Easterbrook and Fischel make in several articles is that investors can easily diversify their portfolios and that a decision that disfavors one party to a corporate transaction will benefit the other. Thus, so long as total gains exceed total losses, investors profit. See Easterbrook \& Fischel, Corporate Control Transactions, 91 YALE L.J. 698, 711-14 (1982). Easterbrook and Fischel consequently argue that "the fiduciary principle should incorporate a wealth maximization standard, that an unequal division of gains from corporate control transactions facilitates wealth maximization, and that corporation law almost never requires gain sharing." Id. at 737.

Other commentators disagree vigorously with Easterbrook and Fischel's line of argument and conclusions. See, e.g., Brudney, Equal Treatment of Shareholders in Corporate Distributions and Reorganizations, 71 CAL1F. L. REv. 1072, 1083-87 (1983). Still others point out that if the stock market is relatively rather than perfectly efficient, then Easterbrook and Fischel's central argument becomes problematic. See Gordon \& Kornhauser, Efficient Markets, Costly Information, and Securities Research, 60 N.Y.U. L. REV. 761, $831-33$ (1985). 
corporate governance rules will have systematic effects, they must assume that courts will apply those rules in a relatively uniform and therefore predictable fashion to all cases that involve similar governance issues-for example, that courts will defer equally to all business decisions made by directors who have no ostensible financial or familial interest in those decisions. Such predictability is necessary to provide commentators (and imvestors) with a reasonable basis for reaching informed judgments about whether any given corporate governance rule will advance or mjure shareholders' interests generally. Furthermore, since they take it as a given that the stock market usually is the best unbiased mdicator of the significance of new information, the contractoriented commentators conclude that investors can be expected to respond positively to a judicial decision that changes corporate governance rules in a manner that increases shareholders' wealth generally, even where that decision is adverse to the immediate interests of shareholder plaintiffs in the transaction under review. ${ }^{24}$

Fischel, writing alone, made this argument explicitly and linked it to the ongoing debate about the dynamics of the market for corporate charters. $^{25}$ Specifically, Fischel criticized the Delaware Supreme Court's decisions in four cases decided after Cary published his critique of Delaware's corporate jurisprudence, all four of which involved rulings in favor of shareholder plaintiffs. Each of the four, Fischel claims, will produce adverse systematic effects that will reduce shareholders' wealth. ${ }^{26}$ The trend in Delaware law evidenced by these four decisions, Fischel writes, "poses a threat to the continued primacy of Delaware."27 If the Delaware Supreme Court persists in rejecting the nonregulatory approach that it previously had pursued and continues to issue decisions that discourage wealth-1naximizing transactions, the appeal of incorporating in Delaware will be lost. Investors will react, and corporations inay begin to leave Delaware for other domiciles with systems of corporate law better attuned to maximizing shareholders' wealth. ${ }^{28}$

24. This argument is based in part on the ECMH, which Easterbrook and Fischel have embraced. See Easterbrook \& Fischel, supra note 21, at 1165-68; Easterbrook, Managers' Discretion and Investors' Welfare: Theories and Evidence, 9 DEL. J. CORP. L. 540, 548-49 \& n.11 (1984).

25. Fischel, The "Race to the Bottom" Revisited: Reflections on Recent Developments in Delaware's Corporation Law, 76 Nw. U.L. REv. 913, 943-44 (1982).

26. The effect of Singer v. Magnavox Co., 380 A.2d 969 (Del. 1977) "is to reduce shareholder wealth ex ante, because it decreases the number of value increasing transactions by increasing the costs of consummating such a transaction." Fischel, supra note 25 , at 928 (footnote omitted). Similarly, the effect of the court's two decisions in Lynch v. Vickers Energy Corp., 383 A.2d 278 (Del. 1977) (Lynch I) and Lynch v. Vickers Energy Corp., 429 A.2d 497 (Del. 1981) (Lynch II) "will be to decrease the incidence of value-increasing transactions." Fischel, supra note 25, at 934. Finally, "the effect of [Zapata Corp. v.] Maldonado, [430 A.2d 779 (Del. 1981),] like the effect of Singer and Lynch, will be to reduce shareholders' welfare." Fischel, supra note 25, at 941.

27. Fischel, supra note 25 , at 942.

28. Id. 
The controversy between Cary and Winter and the writings of Easterbrook and Fischel ${ }^{29}$ suggest two empirically testable hypotheses. One is that investors will react, and the price of a coinpany's stock will change, when the inarket learns that a company plans to reincorporate in Delaware. The other is that the price of the stock of Delaware companies will change when the market learns of substantial changes in Delaware corporation law.

We tested empirically the second of these hypotheses. Before describing our study, it is useful to briefly review three empirical studies that have addressed the first hypothesis, to make clear why we consider the results of these studies to be inconclusive, and to point out the relationship of the first hypothesis to the second.

\section{B. Market Studies Concerning the Effects of Reincorporation in Delaware}

Peter Dodd and Richard Leftwich were the first to evaluate the impact on stock prices of announcements that companies planned to reincorporate in Delaware. ${ }^{30}$ Information about state corporation laws is publicly available, and Dodd and Leftwich assumed "that investors [will] weigh the costs and benefits of alternative state corporation codes when they consider investments in securities of firms incorporated in particular states."31 The ECMH suggests that movement in stock prices should provide an accurate indication of investors' reactions to reincorporation announcements. Thus, it seemed to follow that if Delaware law created more opportunities for exploitation of shareholders' interests than did the laws of other states, then the price of a company's stock would decline when the coinpany announced that it planned to reincorporate in Delaware. $^{32}$ Likewise, if Delaware law facilitated more efficient corpo-

29. Other attempts to evaluate the systematic impact of judicial decisions concerning issues of corporate governance include Ruback, An Economic View of the Market for Corporate Control, 9 DEL. J. CORP. L. 613 (1984). For an example of how this pattern of analysis may be influencing the courts' thinking, see Beerly v. Department of Treasury, 768 F.2d 942, 946-47 (7th Cir. 1985) (Posner, J.) (ability of outsider to pay premium rates for controlling shares facilitates "effectiveness of the market for corporate control . . . in moving corporate resources into the hands of those who can get the most value out of them"), cert. denied, 106 S. Ct. 1184 (1986).

30. Dodd \& Leftwich, The Market for Corporate Charters: "Unhealthy Competition" versus Federal Regulation, 53 J. Bus. 259 (1980).

31. Id. at 261. Dodd and Leftwich also assumed that managers make the choice of where to incorporate "using, in principle, the same cost-benefit calculus that is involved in other decisions such as selecting plant sites." Id. at 260 . This assumption does not seem very important, for two reasons. First, it is unclear what elements they included in the "cost-benefit calculus" to which they referred, and specifically, what role they assigned to managers' personal interests. Second, since their study focused on investor behavior, the factors that motivate managers' decisions are largely irrelevant to their results, except to the extent that the market forces managers to represent faithfully their shareholders' best interests.

32. Dodd and Leftwich thus assumed a testable interpretation of Cary's work: that Delaware 
rate operations, as suggested by Winter, then one would expect a reincorporation announceinent to be followed by an increase in the price of that company's stock.

Dodd and Leftwich found no statistically significant abnormal positive or negative returns associated with firms' reincorporation announcements. ${ }^{33}$ These results, they concluded, repudiate Cary's "stockholder exploitation hypothesis." 34 In addition, Dodd and Leftwich asserted that "[t]he evidence is consistent with our [cost avoidance] hypothesis that managers of a firm take advantage of the competition among states to locate in a state which offers an efficient set of restrictions on the firm, given the firm's anticipated production-investment and financing decisions."35

Whether Dodd and Leftwich's results support their unequivocal rejection of Cary's arguments is not, however, quite so clear. Their results are inconsistent with the claim that Delaware law allows more exploitation than the law of other states, but not with the claim that state corporate laws, in general, represent a lowest common denominator designed to appeal to corporate managers. ${ }^{36}$

Moreover, Dodd and Leftwich's results innply alinost nothing about either Cary's substantive critique of various aspects of Delaware law or Winter's responses thereto. That is, one who accepts Dodd and Leftwich's assumptions-that there exist material differences between states' corporation laws and that investors will react to those differences-would not necessarily conclude that the price of a company's stock will change significantly when a company announces its plans to reincorporate, whether in Delaware or in some other state. An investor seeking to evaluate a reincorporation announcement must consider all the differences between the corporate laws of the company's current domicile and the corporate laws of its target domicile, not merely differences in a few selected aspects of each state's laws. Should the investor

law provides less protection to shareholders than do the laws of other states. If they had read Cary to assert that all states' laws insufficiently protect shareholders, that Delaware law is not significantly better or worse than that of other states, and that investors react to the inadequacy of state law by investing less in corporate stock, it seems clear that they could not have tested empirically Cary's thesis.

33. Dodd \& Leftwich, supra note 30, at 277. Dodd and Leftwich found that firms choosing to reincorporate had experienced substantial abnormal positive returns in the 24 -month period prior to reincorporating, but did not link those returns to the reincorporation decision. Id. at 275-77. Other commentators have cited Dodd and Leftwich's results in support of claims that Delaware has developed a superior body of corporate law, but have not explained why those results should be so interpreted. See, e.g., Easterbrook, supra note 24, at 550.

34. "[S]tockholders are not made worse off when firms switch state of incorporation, even when they switch to that much-maligned state of Delaware." Dodd \& Leftwich, supra note 30, at 281.

35. Id. at 282 .

36. Recall that Cary's artiele is ambiguous on this point. See supra text accompanyiug note 13. 
determine that the detrimental and advantageous features of the two states' laws balance each other out, he presumably would not change his valuation of the subject company's stock.

For example, an investor might well view as advantageous the provision of Delaware law allowing a simple majority of shareholders (rather than a super-majority) to approve major corporate transactions, ${ }^{37}$ but might beheve that the Delaware courts' reluctance to evaluate transactions on a de facto (rather than a de jure) basis makes shareholders vulnerable to exploitation. Absent evidence allowimg one to disaggregate investors' reactions to specific features of Delaware law, the ouly conclusion one reasonably can draw from the market's failure to react to remcorporation announcements is that Delaware law, taken as a whole, is not materially less favorable to investors than the corporate laws of other states. ${ }^{38}$ Dodd and Leftwich's results do not support either the conclusion that any particular aspect of Delaware corporate law is either superior or inferior to comparable aspects of the corporate laws of other states, or the conclusion that state laws in general adequately protect shareholders' interests.

Despite these limitations, the Dodd and Leftwich study represents a valuable first effort to investigate empirically competing theories concerning both the dynamics of what some call the "inarket for corporate charters" and the substantive inerit of different states' corporate laws. The study also raised, but did not seek to answer, two very interesting related questions: (1) Given the differences that exist between different states' corporate laws, what factors explain individual firms' decisions as to where to incorporate? and (2) Why do so many firms choose to incorporate in Delaware? Two subsequent studies, one by Barry Baysinger

37. One could argue that such rules are advantageous because they make it more difficult for a minority of shareholders to behave strategically by blocking transactions preferred by a majority, or because they reduce the costs that corporations must incur in obtaining the requisite vote in favor of transactions that shareholders almost always approve.

Often, too, it is difficult to determine whether a given rule helps or injures shareholder interests. Consider Cary's criticism of $\S 228$ of the Delaware Code, which allows companies to act on the basis of written consents from a majority of shareholders, rather than requiring that shares be voted at a shareholders' meeting. Cary objected to this provision as offering managers a technique for avoiding disclosure. Cary, supra note 2, at 669 . Yet in recent years, many raiders have used Delaware's consent procedure to consolidate their control over target companies more rapidly, causing a number of corporate managements to sponsor proposals to disallow their shareholders from acting through the use of consents.

38. If managers choose to move to Delaware because its corporate law provides more scope for self-aggrandizement, and if shareholders do not think they are worse off when firms reincorporate in Delaware, one could view a move to Delaware as a Pareto improvement, in that one group is better off and the other is not worse off. This interpretation of Dodd and Leftwich's results is consistent with the view that some aspects of Delaware law promote more efficient corporate operations and others benefit managers at the expense of shareholders. It also suggests that managers of firms that reincorporate in Delaware, on average, arrogate to themselves gains equal in value to the efficiency gains that their firms realize by operating under Delaware law. 
and Henry Butler ${ }^{39}$ and the other by Roberta Romano, ${ }^{40}$ provide insights relevant to those questions.

Baysinger and Butler start from the premise that the existence of different state systems of corporate law promotes efficient corporate operations because it allows managers to choose the system-or "standard form contract" - that best suits their firm's ownership structure. ${ }^{41}$ Moreover, because different systems are best for different firms, the financial performance of firms chartered in different states should not vary as a function of where those firms are mcorporated. ${ }^{42}$ State systems, Baysinger and Butler assert, can be classified as "strict" or "liberal." "Strict laws provide a relatively greater scope for the involvement of shareholders in managing the firm; liberal laws reduce direct controls by shareholders and emphasize the anonymous mechanism of the stock market." ${ }^{43}$ Baysinger and Butler classify California, Illinois, New York, and Texas as "strict" states and Delaware as "liberal." 44

Because strict laws enhance shareholders' ability to influence managers' decisions, Baysinger and Butler hypothesize that firms with relatively more concentrated share ownership should tend to choose to incorporate or remain incorporated in states that have such laws. ${ }^{45}$ Such firms also should tend to attract new investors who are interested in establishing large ownership positions in the firms in which they invest.

To test these hypotheses, Baysinger and Butler measured the ownership characteristics both of large, publicly-held firms that have chosen to remain incorporated in the four above-mentioned "strict" states, and of firms that have chosen to leave those states and reincorporate in Delaware. The results of their empirical analysis, they state, fail to refute their hypothesis that managers' choices of where to incorporate reflect the interests of their firms' shareholders. ${ }^{46}$ More specifically, firms with concentrated ownership interests "are less likely to migrate [to Delaware] than firms with more dispersed ownership structures, all else

39. Baysinger \& Butler, The Role of Corporate Law in the Theory of the Firm. 28 J.L. \& ECoN. 179 (1985).

40. Romano, Law as a Product: Some Pieces of the Incorporation Puzzle, 1 J.L. Econ. \& Org. 225 (1985).

41. Baysinger \& Butler, supra note 39 , at $179-80$.

42. Id. at 184. This prediction is consistent with the results of the Dodd and Leftwich study. See supra text accompanying note 30. Baysinger and Butler also assert that Dodd and Leftwich found that "firms reincorporating in Delaware experienced an unexpected increase in sharc prices." Baysinger \& Butler, supra note 39, at 188. While this statement is true as far as it goes, the more relevant finding of Dodd and Leftwich was that no significant changes in share prices were associated with firms' announcements of their intent to reincorporate in Delaware.

43. Baysinger \& Butler, supra note 39 , at 181.

44. Id. at 184-85.

45. Id. at 183 .

46. Id. at 190. 
equal."47 In addition, Baysinger and Butler found that the performances of firms that stay and those that leave were roughly comparable.

We have serious questions about Baysinger and Butler's classification system ${ }^{48}$ as well as their methodology. ${ }^{49}$ More significantly, for our purposes, their study implies nothing about whether a state law rule relating to any particular corporate governance issue is more or less likely to proinote efficient corporate operations. As was the case with Dodd and Leftwich, Baysinger and Butler treat state corporate laws as systems; tlius their results could just as easily involve situations in whicl1 investors evaluated certain aspects of "strict" systems as beneficial and otliers as detriinental. However, Baysinger and Butler's results do provide indirect support for one of the assumptions on which Dodd and Leftwicl based their study, namely, that investors are responsive to differences in state rules of corporate law. Sucli responsiveness is consistent with the correlations tliat Baysinger and Butler found between ownership patterns and "strict" and "liberal" states.

Roberta Roinano subsequently publislied a muclı more ambitious study of the dynarmics of the incorporation process, imvolving an analysis of both the supply and demand sides of the market for corporate charters. ${ }^{50}$ On the supply side, Roinano found tliat Delaware was far more dependent on franchise taxes than any other state, and that Delaware was by far tlie most responsive state in terms of enacting changes in corporate law that corporations deem desirable. ${ }^{51}$ This correlation, she pos-

47. Id. However, firms that stay in strict states do not attract more in the way of new investment from concentrated ownership interests than do firms that migrate to Delaware. Richard Posner and Kenneth Scott also have suggested that Delaware corporate law is particularly attractive to large, publicly-held firms. R. POSNER \& K. SCOTT, ECONOMICS OF CORPORATION LAW AND SECURITIES REgULATION 111 (1980).

48. Baysinger and Butler do not make clear whether their classification of state systems is based on the existence of rules that give shareholders more voice in corporate decisionmaking, such as provisions requiring that mergers must be approved by two-thirds of a company's shareholders, or on standards that allow shareholders more scope to challenge managers' decisions on equitable grounds. Their reference to "direct controls by shareholders" in the quoted passage, see supra text accompanying note 43 , suggests that they are more concerned with rules than with standards. However, they recognize elsewhere that the critical differences between different state systems may relate not to rules but to how different states' courts interpret the character of managers' fiduciary duties. Baysinger \& Butler, supra note 39, at 180 n.4.

Roberta Romano points out that New York, one of the four states Baysinger and Butler classify as "strict," is a relatively permissive state, and that several states that Baysinger and Butler classify as "permissive" should, using their criteria, be classified as "strict." Romano, The State Competition Debate in Corporate Law, 8 CARdozo L. REV. 709 (1987).

49. Baysinger and Butler compare the characteristics of the firms that chose to remain in "strict" states with the characteristics of those that chose to migrate to Delaware. Baysinger \& Butler, supra note 39 , at 185 . But they never indicate what changes in firm characteristics or in environment cause the "leavers" to migrate. For their purposes, a better comparison would have been between firms incorporated in "strict" jurisdictions and those incorporated in Delaware.

50. Romano, supra note 40 .

51. Id. at 240. This finding is consistent with Cary's claims conceruing the manner in which 
tulated, is the result of a "captive" relationship. As a state becomes more dependent on franchise taxes as a source of revenue, it also comes under pressure to mamtam that source of revenue by amending its corporate laws to ensure that corporations do not depart to some other jurisdiction whose laws have become more attractive.

Romano acknowledges that the evidence indicating that states compete implies nothing as to whether the laws generated by that competition are more beneficial to managers or to shareholders. To deal with that issue, she engaged in a two-stage research effort. First, she surveyed firms concerning their reasons for remcorporating in Delaware or for remainimg domiciled in other states. She found that, in general, firms chose to remcorporate when they anticipated imvolvement in transactions that made Delaware law more attractive: in advance of going public, in anticipation of embarking on acquisition programs, or in order to obtain the protection afforded by state takeover legislation.

Second, Romano conducted an event study ${ }^{52}$ of stock market reactions to remcorporation decisions, for purposes of which she assigned reincorporating firms to one of three groups, depending on whether the firms had reported that they remcorporated to secure antitakeover protection, to facilitate a planned merger and acquisition program, or for tax or other reasons. ${ }^{53}$ She found positive cumulative average residuals ${ }^{54}$ for all three groups, but only for the mergers and acquisitions group were her results statistically significant at the one-percent level. ${ }^{55}$

We believe Romano's results may be inethodologically flawed. Her focus is on cumulative residuals over a period of time beginning ninety-

state legislatures compete. See supra note 13. Also consistent with Cary's claims is Romano's finding of a statistically significant correlation between states' dependence on franchise taxes and states' responsiveness to demand for changes in their corporate laws. Romano, supra note 40 , at 239-40.

52. Event studies evaluate the effect on stock prices of a single event such as reincorporation. Abnormal returns accruing to the stock on the event date are interpreted as an index of the economic impact of the event on the firm's value. In order to determine whether a stock experiences abnormal returns, event studies generally use the market model, a version of the capital asset pricing model, as a model of the process generating normal returns. The differenee between the market model's predicted rate of return and the actual rate is the measure of abnormal returns. Romano, supra note 40, at 266; see also infra note 66.

53. As with the earlier studies that tried to measurc the market's reaction to reincorporations, Romano faced difficulty in isolating the date on which investors were likely to have learned that a firm planned to reincorporate. She used the earliest of six possible dates, apparently on the theory that information about planned reincorporations is unlikely to be kept secret and investors can be expected to react to information as soon as it becomes available. Romano, supra note 40, at 268.

54. For an explanation of cumulative average residuals, see infra text following note 153 .

55. That is, under a null hypothesis of no relationship, Romano's statistical results had less than a one-percent probability of occuring because of pure chance or randomness. Romano, supra note 40, at 268-71. Romano also found the cumulative average residual for the three groups together to be statistically significant, but noted that the positive residuals were attributable primarily to the merger and acquisitions group, which comprised 63 of the 150 firms surveyed. Id. at $268,271$. 
nine trading days prior to the earhest date $(D)$ on which information about a firm's plans to reincorporate were likely to be known by investors $^{56}$ and ending ninety-nine tradiug days after $D$. In all cases, however, most of the positive returns were geuerated prior to $D$. For example, for the merger and acquisition group, which generated the most significant positive returns, the cumulative residual was 0.060 at ten days before $D$, increased to 0.069 by $D$, and further increased to 0.082 by ten days after $D$. In other words, 73 percent of the positive returns found ten days after $D$ already existed ten days before $D$, and 84 percent of the positive returns found ten days after $D$ were already present in stock prices at $D .57$

We recognize that the positive residuals Romano found prior to $D$ may be attributable to leakage of information about the pending reincorporations and positive market reactions thereto, but there are other plausible explanations for those residuals. ${ }^{58}$ More importantly, the merger-facilitating provisions of Delaware law are nore significant to the shareholders of acquired firms than of acquiring firms. For example, an acquiring firm will not be concerned about whether a simple (rather than a two-thirds) majority of the firm's shareholders can approve a merger if it can structure the transaction as a triangular nierger. In that event, state law will require no vote by the acquiring firm's shareholders. Similarly, whether judicial appraisal is available to shareholders of an acquiring firm rarely will be important, since shareholders of such firms generally can expect to receive no more than prevailing market prices if they seek this reinedy. ${ }^{59}$ Thus, it is hard to see why investors would consider it significant that firms planning to make acquisitions (rather than to be acquired) had decided to reincorporate in Delaware.

Romano's work provides several new and important insights into

56. See supra note 53.

57. Similar observations can be made about the other two groups.

58. For example, the merger-facilitating provisions of Delaware law mentioned by Romano are salient to stock-for-stock transactions, not to cash transactions. Investors may have reacted positively to firms' announcements of plans to use stock to make acquisitions, particularly in the late 1960's, when many aggressive young companies used exotic securities to acquire older, more established businesses. In addition, imvestors may have reacted positively to announcements of reincorporation decisions not because of differences in state law but because those announcements seemed to confirm the firms' acquisition plans.

59. See, e.g., In re Deutschmann, 116 N.Y.S.2d 578, 582 (1952) (where market price on six stock exchanges on appraisal date accurately represents the perceptions of buyer and seller, dissenting shareholders cannot reasonably assume that their shares warrant a higher appraisal value). Cf. Seaboard World Airlines v. Tiger Int'l, 600 F.2d 355 (2d Cir. 1979) (noting cases, including Deutschmann, that relied on market price to establish appraisal value); Leighton v. AT\&T, 397 F. Supp. 133 (S.D.N.Y. 1975) (discussing New York statute which requires that a corporation extend to dissenting shareholders a price "which the corporation considers to be their [shares'] fair value" and which provides that a court establish the price where a shareholder disputes the corporation-established value). 
what she terms "the incorporation puzzle."60 But with respect to questions concerning whether particular aspects of Delaware law either advance or injure shareholders' interests, her study provides no more relevant evidence than did the works of Dodd and Leftwich or Baysinger and Butler.

\section{Our Research Effort: A Market Study Concerning the Effects of Changes in Delaware Corporate Law}

Our study involved examination of inarket reactions to seven Delaware court decisions. We sought to test the hypothesis that the price of the stocks of Delaware companies will change when the market learns of substantial changes in Delaware's corporate governance rules. This hypothesis is based on three subordinate hypotheses, all of which play prominent roles in the works of the contract-oriented commentators. They are:

(1) Investors consider corporate governance rules when they decide whether to purchase or sell a coinpany's stock and react to significant changes in or differences between those rules. ${ }^{61}$

(2) Judge-made corporate governance rules can and should be evaluated in terms of how they affect the wealth of shareholders in compamies other than those involved in the cases in which the rules are announced. ${ }^{62}$

(3) The rules announced by Delaware courts in several recent cases significantly affect shareholders' welfare. $^{63}$

Past tests of the ECMH deinonstrate that securities prices rapidly incorporate new publicly-available information. In other contexts, new judicial decisions apparently have caused statistically significant changes

60. Perhaps the most important insight is that outside counsel, rather than managers or shareholders, tend to exert the strongest influence on firms' decisions as to where to incorporate. Romano, supra note 40 , at 273 . Romano points out that once attorneys have invested in understanding Delaware law, it is more efficient for them to deal with that state on a long-term basis and to encourage new clients to incorporate in Delaware. Other factors that may make Delaware attractive to corporate counsel include predictability, which allows an attorney more frequently to offer unqualified advice, and "liberality," which increases the probability that an attorney will be able to respond affirmatively to client inquiries as to whether certain kinds of transactions can be pursued. Id. at 274-75. Our impression, based on our personal knowledge, is that most attorneys prefer being in a position to offer clear advice to their clients to being in the position of having to explain that the relevant law is complex or unsettled, and that most also prefer situations in which they can respond positively to questions from clients to situations in which they must be nay-sayers.

61. This hypothesis is central to Winter's argument. See supra text accompanying notes 17-20. It also underlies the empirical studies of reincorporation decisions.

62. This hypothesis is central to much of the work of Easterbrook and Fischel. See supra text accompanying notes 21-24.

63. Fischel made this claim explicitly with respect to four of the decisions we studied. See supra note 26. He, alone or with Easterbrook, expressed similar views about the others. See infra notes $74 \& 77$. 
in securities prices. ${ }^{64}$ Thus, it seemed reasonable to expect investors to react to major corporate law decisions such as the seven Delaware court decisions we studied. Specifically, if any of the seven decisions affected shareholders' wealth adversely, investors would have reduced the prices they were prepared to pay (or accept) for the stock of Delaware companies. Conversely, if any of the seven decisions affected shareholders' wealth positively, investors would have increased the value they placed on the stock of Delaware companies. In either event, if investors reacted to any of the seven decisions, their reactions would provide support either for the critics of those decisions or for those who have applauded them. ${ }^{65}$

II

Research Design, Methodology, and Results

Initially, our research effort was to use the standard "market

64. See, e.g., Burns, The Competitive Effects of Trust-Busting: A Portfolio Analysis, $85 \mathrm{~J}$. PoL. EcoN. 717 (1977) (Sherman Act dissolutions of Standard Oil, American Tobacco, and American Snuff); Eckbo \& Wier, Antimerger Policy Under the Hart-Scott-Rodino Act: A Reexamination of the Market Power Hypothesis, 28 J.L. \& EcoN. 119, 134 n.25 (1985) (positing that where investors believe a merger is unlikely, returns to the bidder firm are abnormally large if the merger occurs); Stillman, Examining Antitrust Policy Towards Horizontal Mergers, 11 J. FIN. EcoN. 225 (1983) (examining daily stock return data for companies involved in eleven horizontal mergers during 1964 through 1972); Wier, The Costs of Antimerger Lawsuits, 11 J. FIN. ECON. 207 (1983) (demonstrating that two of five portfolios of defendant companies suffer abnormal losses after antimerger decisions are announced); cf. Eckbo, Horizontal Mergers, Collusion, and Stockholder Wealth, 11 J. FIN. EcoN. 241 (1983) (measuring the market reaction to antitrust complaints challenging horizontal mergers in the mining and manufacturing industries); Garbade, Silber \& White, Market Reaction to the Filing of Antitrust Suits: An Aggregate and Cross-Sectional Analysis, 64 REv. EcoN. \& STATISTICS 686 (1982) (finding that the filing of antitrust suits results in statistically significant decline in stock). But see Ellert, Mergers, Antitrust Law Enforcement, and Stockholder Returns, 31 J. FiN. 715 (1976) (determining that shareholder returns following antitrust decisions were not statistically different from shareholder returns in companies with similar risk).

Cipollone v. Liggett Group, Inc., 789 F.2d 181 (3d Cir. 1986) provides strong anecdotal evidence of the manner in which a judicial decision can influence securities prices. In Cipollone, the Third Circuit ruled that the health warnings required by federal law protect tobacco companies from claims that they failed to provide adequate notice of the dangers of smoking. Id. at 187. In the two days following announcement of that decision, the stock price of all three leading cigarette manufacturers rose by more than ten percent. See Lewin, Tobacco Companies' Victory, N.Y. Times, Apr. 11, 1986, at D1, col. 3.

65. One of the authors of this Article has expressed sympathy for the Delaware Supreme Court's efforts in Singer and Lynch II to address the problems posed by potentially exploitative cashout transactions, albeit while criticizing the rationale of the Delaware court's decisions. See Weiss, The Law of Take Out Mergers: A Historical Perspective, 56 N.Y.U. L. REv. 624, 626, 675, 691 (1981) [hereinafter Weiss, Historical Perspective]. He also has praised Weinberger v. UOP, Inc., 457 A.2d 701 (Del. 1983), another decision we studied. See Weiss, Balancing Interests in Cash-Out Mergers: The Promise of Weinberger v. UOP, Inc., 8 DEL. J. CORP. L. 1 (1983) [hereinafter Weiss, Balancing Interests]. With regard to Zapata, his view also is generally favorable. He did not claim that those decisions would have systematic (as opposed to transactional) effects, but he expected that the market's reactions to those decisions, if any, would be positive. 
model" $" 66$ to measure investors' reactions to six Delaware court decisions, including the four criticized by Fischel. ${ }^{67}$ Three of the decisions Fischel discussed, Singer v. Magnavox, ${ }^{68}$ Lynch $I,{ }^{69}$ and Lynch $I I,{ }^{70}$ relate to regulation of mergers; to these we added a fourth merger-related decision, Weinberger v. UOP, Inc. ${ }^{71}$ Fischel also criticized the Delaware Supreme Court decision in Zapata Corp. v. Maldonado, ${ }^{72}$ for reasons set forth below, we decided to measure investors' reactions to the chancery court decision in that case as well. ${ }^{73}$ When we found no significant market reaction to any of these six decisions, we extended our research effort to measure the market's reaction to the Delaware Supreme Court decision in Unocal Corp. v. Mesa Petroleum Co., ${ }^{74}$ which involved the legality of certaim innovative defensive tactics-a matter concerning which investors have demonstrated considerable sensitivity in related contexts. ${ }^{75} \mathrm{We}$

66. The market model is extensively explained by Eugene Fama in E. FAMA, Foundations OF FINANCE 66-77 \& 69 equation (10) (1976). The market model is commonly used in studying the effects of certain events. See, e.g., Bradley \& Wakeman, The Wealth Effects of Targeted Share Repurchases, 11 J. Fin. Econ. 301, 306-07 (1983); Dann \& DeAngelo, Standstill Agreements, Privately Negotiated Stock Repurchases, and the Market for Corporate Control, 11 J. FIN. Econ. 275, 285-88 (1983); Eckbo, supra note 64, at 251; Linn \& McConnell, An Empirical Investigation of the Impact of 'Antitakeover' Amendments on Common Stock Prices, 11 J. FIN. Econ. 361, 374-78 (1983); Ruback, Assessing Competition in the Market for Corporate Acquisitions, 11 J. FiN. Econ. 141, 14446 (1983); Schipper \& Thompson, Evidence on the Capitalized Value of Merger Activity for Acquiring Firms, 11 J. Fin. ECON. 85, 94-98 (1983); Stillman, supra note 64, at 234; Wier, supra note 64, at 214-16.

67. See supra notes 25-27 and accompanying text.

68. Singer v. Magnavox Co., 380 A.2d 969 (Del. 1977).

69. Lynch v. Vickers Energy Corp., 383 A.2d 278 (Del. 1977). For convenience, we refer to this Delaware Supreme Court decision as Lynch $I$.

70. Lynch v. Vickers Energy Corp., 429 A.2d 497 (Del. 1981). For convenience, we refer to this Delaware Supreme Court decision as Lynch $I I$.

71. 457 A.2d 701 (Del. 1983).

72. 430 A.2d 779 (Del. 1981).

73. Maldonado v. Flynn, 413 A.2d 1251 (Del. Ch. 1980), rev'd sub nom. Zapata Corp. v. Maldonado, 430 A.2d 779 (Del. 1981). For convenience, we refer to the Delaware Court of Chancery decision as Maldonado, and the Delaware Supreme Court decision as Zapata.

74. 493 A.2d 946 (Del. 1985). Fischel would not have viewed this decision as favorable to investor interests. See Easterbrook \& Fischel, supra note 21.

75. See Jarrell, The Wealth Effects of Litigation by Targets: Do Interests Diverge in a Merge?, 28 J.L. \& ECON. 151 (1985) (evaluating target management's litigation defense strategy); Jensen \& Ruback, The Market for Corporate Control: The Scientific Evidence, 11 J. Fin. Econ. 5 (1983) (suggesting that targeted large-block repurchases and standstill agreements harm shareholders).

We also considered threc additional recent Delaware court decisions as possible candidates for analysis. Two cases we rejected because both decisions were announced on the same day, thus making it impossible to determine to which decision, if either, the market might be reacting. Moran v. Household Int'l, Inc., 490 A.2d 1059 (Del. Ch. 1985) (approving adoption of "poison pill" to fend off unwanted takeover bids); Smith v. Van Gorkom, 488 A.2d 858 (Del. 1985) (holding board's approval of sale of company to unrelated party not protected by business judgment rulc). The third case, Moran v. Household Int'l, Inc., 500 A.2d 1346 (Del. 1985), aff'g 490 A.2d 1059 (Del. Ch. 1985) was problematic because it affirmed (rather than reversed) a chaneery court decision and because its result also was predictable in light of Unocal. See Moran, 500 A.2d at 1350 (citing Unocal as disposing of the key issues in Moran). 
also investigated in greater detail the effect of Singer on Delaware companies with disparate characteristics.

\section{A. Selection of Cases}

Judicial opinions have several attractions as events upon which to base studies of market reactions. Courts traditionally have been very successful in keeping their decisions secret until they are released; thus, information leaks are not likely to be a problem. Moreover, the dates on which decisions are issued can easily be obtained and, since judicial decisions are public documents, it is reasonable to assume that information about decisions is available to investors virtually as soon as courts have filed their opinions. In sum, hittle uncertainty exists as to the date on which the market first learns of the relevant events-the courts' decisions. ${ }^{76}$

One important conceptual problem in attempting to measure market reactions to judicial decisions involves the possibility that the market may have largely anticipated, and therefore impounded in securities prices, the result that a court aunounces. This possibility is substantial where a court's decision is consistent with well-estabhished authorityfor exampIe, a decision applying the busmess judgment rule to a relatively routine corporate transaction. We beheved this possibility would be much smaller where a decision appeared to depart from or reverse well-established authority. Thus, our first research task was to verify that all cases to be studied involved such departures or reversals. ${ }^{77}$

\section{Singer v. Magnavox Co.}

One very inportant issue addressed by the law concerning mergers involves the circumstances in and the grounds upon which shareholders will be allowed to challenge mergers. If shareholders are limited to questioning whether a merger complies with all relevant statutory requirements, the law's certainty and predictability will reduce transaction costs and facilitate consummation of mergers that presumably benefit the corporation and its shareholders. On the other liand, so limiting shareholders will inake it easier for inanagers to consummate unfair mergers, a prospect that is particularly pertinent to mergers where inanagers are affiliated with both the acquired and the acquiring corporations.

For a number of years prior to its decision in Singer v. Magnavox

76. Ascertaining the relevant event date is much more difficult in the case of reincorporation decisions. See supra note 53.

77. Fischel characterized four of the decisions studied as involving "radical departures from prior law." Fischel, supra note 25, at 942 . He also viewed Weinberger as breaking new ground. See Fischel, The Appraisal Remedy in Corporate Law, 1983 AM. B. Found. RES. J. 875, 894-96. 
Co., ${ }^{78}$ the Delaware Supreme Court had placed a premium on certainty and predictability. ${ }^{79}$ It stated that it was not concerned about the purposes of mergers so long as they were carried out in full compliance with statutory procedures, and it held that appraisal was the exclusive remedy available to shareholders dissatisfied with the price they were to receive. $^{80}$

Singer represented a sharp departure from those holdings. The case involved a cash merger of Magnavox into a wholly-owned subsidiary of North American Phillips Company, which had acquired 84.1 percent of Magnavox stock eight months earher through a cash tender offer. Plaintiffs (shareholders of Magnavox) sought to block the merger or to obtain a higher price for their shares, alleging that "the merger was not designed to serve any vahid corporate purpose or compelling business need of Magnavox but rather it was intended solely to remove the public minority shareholders froin equity participation in Magnavox at a grossly inadequate price." 81 The chancery court, relying on well-established principles, dismissed the coinplaint. ${ }^{82}$

The Delaware Supreine Court reversed. It held that a shareholder could maintain an action questioning both the purposes of a cash-out merger and the fairness of the price being offered. Specifically, the court stated that a merger "made for the sole purpose of freezing out minority stockholders, is an abuse of the corporate process" 83 and that, even where such a freezeout was not the sole purpose, the chancery court was obligated to scrutinize the merger to make sure that it was "entirely fair." 84 Thus, where before Singer a cashed-out minority shareholder apparently was limited to seeking a judicial appraisal of the fair value of his shares, after Singer such a shareholder was in a position to initiate a lawsuit on behalf of all minority shareholders challenging both the purpose of the merger and the adequacy of the price offered. Singer also inade it much more difficult to predict how the Delaware courts would

78. 380 A.2d 969 (Del. 1977).

79. See, e.g., Hariton v. Arco Elecs., Inc., 188 A.2d 123 (Del. 1963) (upholding legality of de facto merger accomplished under sale-of-assets statute on grounds that to do otherwise would "create uncertainty in the law and invite litigation").

80. Stauffer v. Standard Brands, Inc., 187 A.2d 78 (Del. 1962) (appraisal exclusive remedy); Federal United Corp. v. Havender, 24 Del Ch. 318, 11 A.2d 331 (1940) (purpose of merger irrelevant if statutes followed); see also David J. Greene \& Co. v. Schenley Indus., Inc., 281 A.2d 30 (Del. Ch. 1971) (following Stauffer); Bruce v. E.L. Bruce Co., 40 Del. Ch. 80, 174 A.2d 29 (1961) (following Havender). The United States Supreme Court and the Second Circuit both premised their decisions in Santa Fe Indus. v. Green, 430 U.S. 462 (1977), rev'g 533 F.2d 1283 (2d Cir. 1976) on the view that appraisal was the exclusive remedy available under Delaware law. See also Weiss, Historical Perspective, supra notc 65, at 655-57 (discussing Santa Fe).

81. Singer v. Magnavox Co., 367 A.2d 1349, 1353 (Del. Ch. 1976).

82. Id. at 1362 .

83. Singer v. Magnavox Co., 380 A.2d 969, 980 (Del. 1977).

84. Id. 
treat any given cash-out merger. ${ }^{85}$

We concluded that it was unlikely that investors had fully anticipated the Singer decision. ${ }^{86}$

\section{Lynch I}

The two Lynch decisions ${ }^{87}$ amplified considerably the theme developed in Singer. They arose out of a cash tender offer that Vickers, a subsidiary of Esmark, Inc., made on September 30, 1974. Vickers was trying to acquire the 46.5 percent of TransOcean Oil, Inc., that it did not already own. In 1971 , TransOcean stock had traded as high as $\$ 30.375$ a share, and im the first quarter of 1974 the high bid had been $\$ 15$. However, TransOcean's stock price slumped to $\$ 6.75$ during the summer of 1974 , and shortly thereafter Vickers made a tender offer at \$12. Vickers' offering circular stated that TransOcean's management had advised Vickers that TransOcean's "net asset value ... is not less than $\$ 200,000,000$ (approximately $\$ 16.00$ per share) and could be substantially greater"88 and that Vickers had acquired its TransOcean stock at an average price of $\$ 11.49$ per share. In fact, TransOcean possessed a report prepared by Harrell, a member of its management, estimating the net value of its assets to be $\$ 250,800,000$. In addition, Esmark's board had authorized Vickers to purchase TransOcean stock, prior to the merger, at prices up to $\$ 15$ per share.

At the first trial, the chancery court rejected the plamtiffs' claim, advanced on behalf of all shareholders who had tendered to Vickers, that the Harrell report and the purchase authorization should have been disclosed. ${ }^{89}$ Since the Delaware Supreme Court previously had held that the disclosure obligations imposed by Delaware law were less extensive than the disclosure obligations imposed by federal law, ${ }^{90}$ the chancery

85. The Singer court explicitly reversed or limited a number of earlier decisions that most commentators had believed governed cash-out transactions. See id. at 978-80; Weiss, Historical Perspective, supra note 65, at 658-60.

86. Most commentators viewed Singer as unexpected. See, e.g., Brudney \& Chirelstein, $A$ Restatement of Corporate Freezeouts, 87 YALE L.J. 1354, 1354 (1978) (Singer's requirement that a purpose other than elimination of the minority shareholders be supported by the evidence generally viewed as a new development in Delaware law); McBride, Delaware Corporate Law: Judicial Scrutiny of Mergers-the Aftermath of Singer v. The Magnavox Company, 33 Bus. LAw. 2231, 2231-38 (1978) (Singer was significant departure from earlier Delaware cases). A few did not. See Rothschild, Going Private, Singer, and Rule 13e-3: What Are the Standards for Fiduciaries?, 7 SEC. REG. L.J. 195, 199-209 (1979) (Singer does not represent a radical departure from earlier cases).

87. Lynch v. Vickers Energy Corp., 351 A.2d 570 (Del. Ch. 1976), rev'd 383 A.2d 278 (Del. 1977) (referred to in this Article as Lynch I); Lynch v. Vickers Energy Corp., 402 A.2d 5 (Del. Ch. 1979), aff'd in part \& rev'd in part, 429 A.2d 497 (Del. 1981) (referred to in this Article as Lynch II).

88. Lynch I, 383 A.2d at 280 (emphasis in original).

89. Lynch v. Vickers Energy Corp., 351 A.2d 570, 574-75 (Del. Ch. 1976).

90. American Hardware Corp. v. Savage Arms Corp., 37 Del. Ch. 59, 64-65, 136 A.2d 690, 693 (1957). 
court's disposition of the plaintiffs' claim appeared to be well-grounded. Indeed, in a related case brought under the federal securities laws by shareholders who had opted out of the Delaware litigation, a federal district court held that the plaintiffs' claims relating to Vickers' failure to disclose the Harrell report and Esmark's purchase authorization raised questions of fact to be decided by the jury. ${ }^{91}$ Thus, even if Delaware law imposed disclosure obligations identical to those imposed by federal law, the chancery court's rejection of the plaintiffs' claims appeared to be based on a presumably irreversible finding of fact.

However, the Delaware Supreme Court reversed. It held that Vickers' failure to disclose the Harrell report and the information about Esmark's purchase authorization constituted, as a matter of law, a breach of Vickers' "fiduciary duty of candor."92 This holding moved Delaware law from a posture of requiring less disclosure than federal law requires to a posture of requiring more; in the process, it expanded considerably the state law grounds on which a shareholder of a Delaware corporation could challenge a tender offer or a merger. Therefore, $L y n c h$ $I$ appeared to qualify as a decision that investors probably could not fully anticipate. $^{93}$

\section{Lynch II}

Lynch $I I^{94}$ involved determination of the damages sustained by the plamtiff class as a result of the breach of fiduciary duty established by Lynch $I$. The chancery court, using the traditional "Delaware block approach" for valuing stock, held that at the time of the tender offer, the fair value of TransOcean stock was $\$ 11.85$ per share. Since that amount was $\$ 0.15$ per share less than Vickers had paid, the court awarded no damages. ${ }^{95}$

Again the Delaware Supreme Court reversed, this time by a 3-2 vote after hearing the case en banc. ${ }^{96}$ The thrust of the supreme court's opinion was that since plaintiffs had been imjured by defendants' breach of their fiduciary duties, plaintiffs were entitled to recover a major share of the gains Vickers realized as a consequence of the sharp, unanticipated rise in oil prices that occurred durmg the four-year period between the

91. In re TransOcean Tender Offer Sec. Litig., 427 F. Supp. 1211, 1224 (N.D. Ill. 1977).

92. Lynch I, 383 A.2d at 281.

93. While one could argue that Singer foreshadowed the result in Lynch $I$, the decision in Tanzer v. International Gen. Indus., Inc., 379 A.2d 1121 (Del. 1977), issued less than a month after Singer, led observers to question the extent to which Singer signalled a major shift in the Delaware Supreme Court's attitude toward judicial scrutiny of mergers and like transactions. See Weiss, Historical Perspective, supra note 65, at 664-66.

94. Lynch v. Vickers Energy Corp., 402 A.2d 5 (Del. Ch. 1979), aff'd in part \& rev'd in part, 429 A.2d 497 (Del. 1981).

95. 402 A.2d at 12 .

96. Lynch v. Vickers Energy Corp., 429 A.2d 497 (Del. 1981). 
tender offer and the end of the trial to establish damages. ${ }^{97}$ The court's innovative approacli to establishing damages placed plaintiffs in a far better position than they would have occupied liad Vickers offered "fair value" for their shares in 1974. As such, it reflected a mucli more punitive attitude toward those wlio engage in arguable violations of their fiduciary duties tlian liad the court's earlier decisions. ${ }^{98}$

It seems unlikely that investors anticipated sucli a result for, as Fischel observes, "the plaintiff's [damage] claim in Lynch appeared to be totally witlout merit" 99 in light of earlier Delaware cases.

\section{Weinberger v. UOP, Inc.}

Weinberger ${ }^{100}$ also dealt witl casli-outs, but in Weinberger the Delaware Supreme Court retreated from soine of its lioldings in Singer, Lynch $I$, Lynch $I I$, and related cases and gave added empliasis to others. Consequently, we included Weinberger in our study as an additional siguificant "event" to whicli investors could be expected to react. ${ }^{101}$

Weinberger involved a caslı merger in whicl Signal, after acquiring a 50.5 percent interest in UOP for $\$ 21$ per sliare in 1975 , acquired the remaining 49.5 percent interest in 1978 at the same price. ${ }^{102}$ Plamtiffs, former shareholders of UOP, brouglit suit cliallenging the merger. They alleged, first, that Signal liad not disclosed certam material information, including the fact that it viewed tlie merger as attractive at any price up to $\$ 24$ per sliare; and second, that the merger was designed solely to freeze out the mimority sliareholders of UOP at an inadequate price. ${ }^{103}$

97. The court ruled that TransOcean's stock should be valued at between $\$ 15$, the amount that Esmark had been prepared to pay, and $\$ 41.40$, the highest value proposed at the trial on damages. Id. at 505 . The court also indicated that asset value should be given substantial weight in determining the stock's value, commenting that the chancery court's decision to assign only a 40 percent weight to asset value was "highly questionable." Id. TransOcean's principal asset was its oil reserves. In 1974, the value of TransOcean's assets had been about $\$ 17.50$ a share. By 1978 (the relevant valuation date), TransOcean's oil reserves were worth much more. The plaintiffs thus seemed assured of collecting a substantial share of the unanticipated gains that Esmark realized when the value of those oil reserves shot up as a result of the activities of the OPEC cartel.

98. See, e.g., Getty Oil v. Skelly Oil Co., 267 A.2d 883, 888 (Del. 1970) (holding that Getty was not required to share valuable oil allocation rights with Skelly, which lost such rights when Getty acquired controlling interest in Skelly).

99. Fischel, supra note 25, at 931. Fischel's frequent coauthor, writing as Judge Easterbrook, appears to have had the final word in the litigation relating to Esmark's acquisition of TransOcean. See Metlyn Realty Corp. v. Esmark Corp., 763 F.2d 826, 832 (7th Cir. 1985) (Easterbrook, J.) (court declines to allow Transocean shareholder to reopen settlement of related federal litigation).

100. Weinberger v. UOP, Inc., 426 A.2d 1333 (Del. Ch. 1981), rev'd, 457 A.2d 701 (Del. 1983), aff'd, 497 A.2d 792 (Del. 1985).

101. Fischel's initial comments on Weinberger were highly critical. Fischel, supra note 77, at 894-96. He has apparently moderated his view of that decision (and of Zapata). See Fischel, The Business Judgment Rule and the Trans Union Case, 40 Bus. LAw. 1437, 1455 n.37 (1985).

102. Weinberger, 426 A.2d at $1335-40$.

103. Id. at 1341 . 
Signal defended in part by contending that purchasing the outstanding 49.5 percent interest in UOP represented the inost attractive investment opportunity available to it. ${ }^{104}$

The chancery court, relying on Singer and its progeny, ${ }^{105}$ held that making a profitable investment constituted a valid purpose for a cash-out merger ${ }^{106}$ and that, using the Delaware block approach, the fair value of UOP's stock was less than $\$ 21 .^{107}$ Accordingly, the court entered judgment for defendants. ${ }^{108}$

A three-judge panel of the Delaware Supreme Court, by a 2-1 vote, affirmed the chancery court's decision. ${ }^{109}$ The court, however, granted plaintiffs' request for a rehearing. ${ }^{110}$ Almost a full year after the panel had spoken, the full court issued an opinion reversing unanimously the chancery court and withdrawing the earher panel decision. ${ }^{111}$

The Weinberger opinion coinprehensively overhauled Delaware law regarding cash-out mergers. The court overruled Singer ${ }^{112}$ and two subsequent decisions that had interpreted Singer's purpose test in a fashion that made it easy for a shareholder to adjudicate the merits of virtually any cash-out merger. ${ }^{113}$ However, the court did not limit disgruntled shareholders to seeking appraisal of their shares. Rather, it indicated that in some circumstances shareholders seeking to challenge a cash-out merger would be limited to seeking appraisal, but in others shareholders would be allowed to proceed by way of class or derivative suits. ${ }^{114}$

The court emphasized that cash-out inergers should be evaluated in terms of whether they were the product of "fair dealing" and whether minority shareholders were being paid a "fair price." 115 It stated that

104. Id. at 1349.

105. The court relied especially on Tanzer v. International Gen. Indus., Inc., 379 A.2d 1121 (Del. 1977), which held that a majority shareholder could arrange a cash-out merger of a controlled subsidiary to advance that shareholder's business interests. See Tanzer, 379 A.2d at 1123-24.

106. Weinberger, 426 A.2d at 1350.

107. Id. at 1362 .

108. Id. at 1363 .

109. No. 58, 1981, slip. op. (Del. Feb. 9, 1982), withdrawn, 457 A.2d 701, 703 n.1 (Del. 1983). The most notable aspect of the panel's opinion was its suggestion that any price representing a substantial premium over prevailing market prices probably could be viewed as fair. Id. at 3-4.

110. Weinberger v. UOP, Inc., 457 A.2d 701, 702-09 (Del. 1983).

111. Id. at 703 n.1.

112. Id. at 704 .

113. See Roland Int'l Corp. v. Najjar, 407 A.2d 1032, 1035-37 (Del. 1979); Tanzer, 379 A.2d at 1123-24; Weiss, Balancing Interests, supra note 65, at 43.

114. Weinberger, $457 \mathrm{~A} .2 \mathrm{~d}$ at 714-15. The court's opinion left unclear the circumstances in which dissident shareholders would be allowed to maintain class actions challenging cash-out mergers. See Weiss, Balancing Interests, supra note 65, at 54-56. A subsequent decision, Rabkin v. Phillip A. Hunt Chem. Corp., 498 A.2d 1099 (Del. 1985) made clear that such actions can be maintained by shareholders who make specific factual allegations that support claims that a merger was not the result of fair dealing. Rabkin, 498 A.2d at 1104-05.

115. Weinberger, 457 A.2d at 711 . 
whether a price was fair should be determined not according to the venerable Delaware block approach (or the more punitive approach endorsed in Lynch II), but by use of a "more liberal" approach that took account of modern valuation techniques. ${ }^{116}$ Finally, it emphasized that in assessing whether a merger was the result of fair dealing, it would pay particular attention to whether full and complete information had been provided to the board and the shareholder of the target company. ${ }^{117}$

Given the number of recent decisions that it overruled, as well as the fact that it reversed an earher panel decision, Weinberger was almost certaiuly unanticipated and represented a najor change in Delaware law.

\section{The Zapata Litigation}

The Zapata hitigation ${ }^{118}$ involved a different set of issues concerming the circumstances in which shareholders can maintain derivative suits. The litigation related to a claim by Zapata shareholders that Zapata's board of directors breached its fiduciary duty by deciding to accelerate the exercise date of certain stock options in order to reduce the tax hability of the option holders. Four years after the shareholders commenced the derivative suit, Zapata formed a board committee, inade up of two newly-appointed directors, to investigate the claims made in this and related federal suits and to take appropriate action on behalf of the corporation. After conducting an investigation, the committee asked the Delaware chancery court to disimiss the suit on the ground that the committee had concluded that prosecution of the plaintiff's derivative claims was not in the best interests of Zapata. ${ }^{119}$

The legal environment in which Zapata was decided led us to conclude that we should evaluate investors' reaction to both the chancery court's decision (Maldonado) and the supreme court's decision (Zapata). Special litigation committees of the sort used by Zapata had become common only in the 1970's, in the wake of disclosures by many large companies that they had made illegal campaign contributions and other kinds of "questionable payments."120 Many of those disclosures precipitated derivative suits seeking to recover the full amount of such payments

116. Id. at 712-13.

117. Id. at 711-12.

118. Maldonado v. Flynn, 413 A.2d 1251 (Del. Ch. 1980) (referred to in this Article as Maldonado), rev'd sub nom. Zapata Corp. v. Maldonado, 430 A.2d 779 (Del. 1981) (referred to in this Article as Zapata).

The same dispute has also been litigated in federal courts in two other states. Maldonado v. Flynn, 485 F. Supp. 274 (S.D.N.Y. 1980), rev'd per curiam, 671 F.2d 729 (2d Cir. 1982); Maher v. Zapata Corp., 490 F. Supp. 348 (S.D. Tex. 1980); see also Maher v. Zapata Corp., 714 F.2d 436 (5th Cir. 1983) (affirming settlement of Texas action, and reviewing history of the related litigation).

119. Maldonado, 413 A.2d at 1254-55.

120. This euphemism was coined in connection with the Security and Exchange Commission's program of requiring corporations to disclose such payments in filings with the Commission. 
from the companies' directors or from the responsible officers. Several companies responded to these suits by appointing special litigation committees, composed of directors who had recently been added to their boards, to determine whether to pursue the derivative claims.

Virtually all of the litigation committees decided that the suits would not serve their company's best interests and moved to have those suits dismissed. In general, courts held that if the directors on a litigation committee had not been imvolved in the challenged payments and the committee had conducted a reasonable investigation of the plaintiff's claims, the court would not look behind the committee's recommendation that prosecution of the suit would not be in the company's best interest. ${ }^{121}$

Relymg on these decisions, a number of companies created special litigation committees to review more traditional derivative suits involving claims that managers had engaged in unfair, self-dealing transactions. When those committees moved to dismiss those suits, courts initially responded in much the same way as they had to litigation committee recommendations concerning questionable payments litigation-that is, where the committee members were disinterested and the committee had made reasonable inquiries, the court granted the committee's motion to dismiss. ${ }^{122}$

In one such case-a compamion case to the Zapata litigation in Delaware ${ }^{123}$ - a federal district court in New York, relying on Delaware law, granted the Zapata litigation committee's motion to dismiss the state and federal derivative claims asserted against Zapata's directors. ${ }^{124}$ However, the Delaware chancery court rejected a similar motion by the same committee to dismiss the derivative suit that the same plaintiff had filed. The chancery court stated:

It is clear ... that under well settled Delaware law, the directors cannot compel the dismissal of a pending stockholder's derivative suit which

121. See, e.g., Abbey v. Control Data Corp., 603 F.2d 724 (8th Cir. 1979), cert. denied, 444 U.S. 1017 (1979). Among other things, upholding the litigation committees' recommendations allowed courts to avoid dealing with the difficult issue of whether payment of a bribe to advance a company's business interests constituted a breach of fiduciary duty for which the company's managers could be held personally liable. See Dent, The Power of Directors to Terminate Shareholder Litigation: The Death of the Derivative Suit?, 75 Nw. U.L. REV. 96, 130-31 (1980).

122. See, e.g., Lewis v. Anderson, 615 F.2d 778 (9th Cir. 1979), cert. denied, 449 U.S. 869 (1980); see also Annotation, Propriety of Termination of Properly Initiated Derivative Action by "Independent Committee" Appointed by Board of Directors Whose Actions (or Inaction) are Under Attack, 22 A.L.R.4th 1206 (1983).

123. Maldonado v. Flynn, 485 F. Supp. 274 (S.D.N.Y. 1980), rev'd, 671 F.2d 729 (2d Cir. 1982).

124. The Eighth Circuit had similarly interpreted Delaware law in a questionable payments case. Abbey, 603 F.2d 724. Another federal district court, in another companion case to Zapata, subsequently denied an identical motion to dismiss. Maher v. Zapata Corp., 490 F.Supp. 348 (S.D.Tex. 1980). 
seeks redress for an apparent breach of fiduciary duty, by merely reviewing the suit and making a busmess judgmeut that it is not in the best interests of the corporation. ${ }^{125}$

Aggrieved stockholders of Delaware corporations enjoy the right to have courts, and "not a committee appointed by the alleged wrongdoers," 126 decide whether their breach of fiduciary duty claims have merit. ${ }^{127}$

Substantial critical commentary had been directed at the earhier litigation committee decisions, ${ }^{128}$ but it seems unlikely that mvestors had anticipated that the Delaware chancery court would adopt a position so different from that of virtually every other court that had dealt with the issue. Thus, it seemed appropriate to measure the market's reactions to both the chancery court decision in Maldonado and the Delaware Supreme Court's subsequent modification of that decision in Zapata. ${ }^{129}$

The supreme court in Zapata held that in a case where the law requires a shareholder plaintiff to make a demand on a coinpany's board of directors, ${ }^{130}$ it would treat as dispositive a board's determination that the suit is not in the coinpany's best interests unless it concludes that the board's determination is "wrongful."131 In a case where demand is excused, it would apply a two-step test to a litigation committee's motion to dismiss. First, it would "inquire into the independence and good faith of the committee and the bases supporting its conclusions." 132 Then, if the committee satisfied the court on these matters, the court would make an independent business judgment as to whether the suit should be maintained, taking account of "matters of law and public policy in addition to the corporation's best interests."133

The supreme court decision in Zapata thus appeared to constitute an event of independent significance. It varied so substantially from the approach adopted by the chancery court that one cannot fairly claim that the chancery court decision foreshadowed what the supreine court would do. At the same time, the supreme court's approach also differed very

125. Maldonado, 413 A.2d at 1257.

126. Id. at 1263.

127. The court also stated that the cases on which other courts had relied to uphold the authority of special litigation committees were inapposite in that they did not involve intracorporate claims of breach of fiduciary duty. Id. at 1257-60.

128. See Dent, supra note 121; Note, Special Litigation Committees: An Expanding and Potent Threat to Shareholder Derivative Suits, 2 CARdozo L. REv. 169, 171-92 (1980).

129. In addition, evaluation of the chancery court decision seemed desirable because that decision made it unclear whether the baseline against which investors would have evaluated the supreme court's decision was the chancery court's ruling or the rulings of other courts on this issue.

130. Demand would be required in a situation where less than a majority of a company's directors were charged with having acted unlawfully. See Aronson v. Lewis, 473 A.2d 805, 814-15 (Del. 1984).

131. Zapata, 430 A.2d at 784 .

132. Id. at 788. The court stated that the committee has the burden of proof on these issues.

133. Id. at 789 . 
substantially from the approach taken by courts interpreting the laws of otlier jurisdictions. ${ }^{134}$ Tlius, it seemed unlikely tliat investors had fully anticipated tliat decision.

\section{Unocal Corp. v. Mesa Petroleum Co.}

The dispute in Unocal ${ }^{135}$ began wlien Mesa, the owner of about 14 percent of Unocal's outstanding stock, inade a tender offer to purchase an additional 37 percent of Unocal's stock for $\$ 54$ cash per share and announced that if that offer was successful, it would acquire the remainder of Unocal in a merger in whicl Unocal shareliolders would receive subordinated debt securities valued at $\$ 54$ per sliare. Unocal's board concluded that Mesa's offer was coercive and grossly inadequate; the board valued Unocal at $\$ 70$ to $\$ 75$ per share. To combat Mesa's offer, Unocal's board autliorized Unocal to exchange $\$ 72$ per share in senior debt securities for up to 49 percent of Unocal's outstanding stock and further provided tliat the excliange offer was not open to Mesa. ${ }^{136}$

Mesa sued to enjoin Unocal from proceeding with the exchange offer. At Mesa's behest, the Delaware chancery court preliminarily enjoined the Unocal offer on tlie ground that Unocal had an obligation to treat all its sliareholders equally. ${ }^{137}$

The Delaware Supreme Court reversed. It held that the actions taken by a corporation's board in response to a takeover threat "are valid exercises of business judgment and entitled to the respect accorded to them by the business judgment rule."138 The court continued: "[W]e are satisfied that in the context of this inadequate tender offer Unocal's action is not so irresponsible and unjustified as to remove it from the ambit of tlie business judgment rule."139

The Unocal decision seemed to represent a break with established Delaware authority and to signal that the Delaware Supreine Court would allow corporate boards wide scope to resist liostile takeover bids. The court itself noted, in its subsequent written opinion, that "no case has ever sanctioned a device that precludes a raider from sharing in a benefit available to all otlier stockholders." 140 Moreover, earlier Delaware decisions seeined to make clear that wliere a transaction did not

134. Coffee \& Schwartz, The Survival of the Derivative Suit: An Evaluation and a Proposal for Legislative Reform, 81 ColuM. L. REV. 261 (1980).

135. Unocal Corp. v. Mesa Petroleum Co., 493 A.2d 946 (Del. 1985) (written opinion); and [1984-1985 Transfer Binder] Fed. Sec. L. Rep. (CCH) \ 92,046 (May 17, 1985) (oral opinion). Our study tested the market's reaction to the supreme court's oral opinion.

136. Unocal, 493 A.2d at 949-51.

137. Id. at 952.

138. Unocal, [1984-1985 Transfer Binder] Fed. Sec. L. Rep. (CCH) \ 92,046, at 92,211.

139. Id. at 92,212 .

140. Unocal, 493 A.2d at 957. 
treat all of a company's shareholders equally, the court would require the company's board of directors to prove that the disparate treatment was fair to all shareholders. ${ }^{141}$ Had the court used this standard to evaluate Unocal's exclusionary exchange offer, it seems clear that Unocal's board could not have demonstrated that the offer was fair to Mesa. ${ }^{142}$

Pogostin v. Rice ${ }^{143}$ had held that the business judgment test should be used to evaluate some defensive tactics, but Pogostin involved considerably less aggressive defensive tactics that affected all target company shareholders equally. ${ }^{144}$ Thus, it can hardly be said that Pogostin clearly foreshadowed the court's decision in Unocal. Indeed, it was Unocal, not Pogostin, that convinced most commentators that the Delaware Supreme Court would allow corporate boards great latitude to respond to tender offers in almost any manner that those boards (or, more precisely, their disinterested meinbers) were prepared to assert would serve to advance the best interests of their company and its shareholders. ${ }^{145}$

\section{B. Market Model Tests}

\section{Methodology}

Since all of the decisions described above inade substantial unanticipated changes in the rules of corporate governance established by Delaware law, it seemed reasonable to expect the share prices of Delaware companies either to rise or to fall significantly following the announcement of those decisions. If investors' unbiased judgment was that a given decision changed the rules so as to increase the welfare of shareholders in Delaware companies, we would expect the share prices of those companies to rise, other things being equal. Conversely, if investors believed that a given decision was adverse to shareholders' interests, we would expect the share price of Delaware companies to fall.

The standard method of neasuring changes im share prices that occur on or about a specific "event" day is to employ the "market model" for ineasuring the returns to holding a stock. ${ }^{146}$ The model assunies that individuals are interested solely in the risk and return of

141. See, e.g., Sinclair Oil Co. v. Levien, 280 A.2d 717 (Del. 1971).

142. All other Unocal shareholders had the opportunity to exchange about one-third of their shares for $\$ 72$ per share in debt securities, but Mesa was consigned to retaining all of its shares. After the exchange offer was completed, those shares had a market value of about $\$ 35$ each.

143. 480 A.2d 619 (Del. 1984).

144. Id. at 627 .

145. Michael Jensen subsequently remarked: "The Delaware Supreme Court surprised the legal, financial and corporate communities in the spring of 1985 by giving Unocal the right to make a tender offer for $29 \%$ of its shares while excluding its largest shareholder, Mesa Partners II, from the offer." Jensen, The Takeover Controversy: Analysis and Evidence 53-54 (April 28, 1986, revision of paper prepared for Columbia Law School Conference on Takeovers and Contests for Corporate Control) (unpublished manuscript on file with the authors).

146. See supra note 66. 
their investments. By holding a diversified portfolio, they are able to smooth out some of the idiosyncratic variance in the individual stocks (the "diversifiable risk"). The risk that cannot be diversified away is the covariance of a stock with the overall market-that is, the extent to which an individual stock's returns (its combination of percentage price changes and dividend returns) vary with the overall market's returns. Thus, to measure the unexpected changes in a stock's price, one first must know the usual pattern of that stock's movements relative to the market's movements.

Formally, then, we employ the following equation as our model:

$$
\tilde{R_{j t}}=a_{j}+\beta_{j} \tilde{R_{m t}}+e_{j t}
$$

(Equation 1)

where:

$\tilde{R_{j t}} \quad=$ the rate of return of stock $j$ during day $t$

$R_{m t}=$ the rate of return of the market portfoho during day $t$

$e_{j t}=$ the error or disturbance term of stock $j$ on day $t$

$a_{j}, \beta_{j}=$ parameters of the relationship between $\tilde{R_{j t}}$ and $\tilde{R_{m t}}$

Using ordinary least squares regression methods, ${ }^{147}$ one can estimate the relationship described in Equation 1 for a given stock for a time period prior to the event in question. In essence, the ordinary least squares estimates provide a baseline that indicates the normal expected behavior of that stock's daily returns given the market's daily returns. The actual behavior of the stock price at the time of the event and shortly thereafter can then be compared with its expected behavior, and standard statistical tests can be used to determine whether, based on the "noisiness" of the pattern of the stock's returns against the market's returns during the pre-event baseline period, the deviation of the actual returns from the expected returns is statistically significant.

\section{Data and Specific Procedures}

To test the effects of the Delaware court decisions, we used samples of approximately fifty companies incorporated in Delaware. ${ }^{148}$ Because

147. The ordinary least squares (OLS) regression method is a way of determining the nature of the statistical relationship between two or more variables. For an explanation of the OLS regression method, see J. JohNSTON, ECONOMETRIC METHODS 171-81 (3d ed. 1984).

148. Because of the overlapping nature of the decisions (and to conserve research assistant resources), three separately drawn samples were used. The first sample was used for Singer, Lynch I, and $L y n c h I I$; the second sample was used for the two Zapata decisions; the third sample was used for Weinberger and Unocal. The first two samples each consisted of Delaware companies drawn randomly from the Fortune 1000 lists of industrials in 1977 and 1980, respectively, excluding numbers 1-100 of those lists. See Alphabetical Index of the 500 Largest Industrials, ForTUNE, May 1977, at 390, and Alphabetical Index of the Second 500 Largest Industrials, FORTUNE, June 1977, at 231-32; Alphabetical Index of the 500 Largest Industrials, ForTUNE, May 5, 1980, at 300, and Alphabetical Index of the Second 500 Largest Industrials, FORTUNE, June 16, 1980, at 201-02. The 
the aggregate market might be heavily weighted with Delaware companies, ${ }^{149}$ making it difficult to distinguish the effects of the decisions on the Delaware companies from their effects on the market, we also collected roughly equal-sized samples of companies incorporated in other states (non-Delaware companies). ${ }^{150}$ Even if the overall market was heavily weighted with Delaware companies, we would still expect to find an opposite effect on the non-Delaware companies relative to the overall market if the described decisions had an effect on Delaware companies.

In all but one instance we used the CRSP tapes of daily returns ${ }^{151}$ for the daily stock returns and the value-weighted CRSP index for the daily market returns. ${ }^{152}$ Treating each of the decisions as a separate event, we calculated Equation 1 for each stock for the period runming from sixty trading days ${ }^{153}$ prior to the event through eleven trading days prior to the event. We terminated the baseline period at eleven trading days prior to the event so that the daily returns withm the two weeks could be examined for suspicious patterns that might indicate leaks of the impending decision. We found none.

We were not able to determine whether the announcements of most of the decisions occurred durimg or after trading hours. Consequently, we arbitrarily labeled the announcement day at $t=0$, and subsequent trading days as $t=1, t=2$, etc. For each announcement, we measured the "abnormal" daily returns of each stock in the sample for the announcement day and for twenty subsequent trading days by calculating the differences between the actual daily returns of the stock and the expected returns of that stock from the estimated baseline, given the daily market returns.

We then summed the daily abnormal returns for each stock into

third sample (also involving 50 companies) was drawn from the Fortune 500 list in 1983, excluding numbers 1-50. See Alphabetical Index to the 500, ForTunE, May 2, 1983, at 252. (Fortune published only 500, rather than 1000 industrials in 1983.) The largest firms were excluded from the samples because the inclusion of extremely large firms, which might be immune to takeovers, could bias the results. The Fortune lists of industrials were used to keep the sample relatively homogeneous and to exclude firms that might be in regulated industries and therefore subject to regulatory delays in takeovers. Though there were 50 companies in each sample for the first event tests, subsequent events tested with the same sample involved slightly fewer than 50 companies due to attrition-for example, through merger.

149. We were not able to determine the fraction of the overall market that consists of companies incorporated in Delaware.

150. We followed the same procedures described in note 148 , supra, to create the sample of nonDelaware companies.

151. The computer tapes provided by the Center for the Study of Security Prices (the CRSP tapes) are a standard source of machine readable daily price and trading data for a large number of publicly traded companies.

152. The CRSP data for the Unocal decision were not yet available. Consequently, we used daily stock price data provided by the Interactive Data Corporation and used the Standard and Poor's 500 Stock Index as our market index.

153. Trading days are days that the stock market is open. 
cumulative abnormal returns (CAR's) through each day $t$. The CAR's for each day were summed separately for each "portfolio" of Delaware and non-Delaware companies. We also coniputed standard errors for these portfolio CAR's, so that tests of statistical significance could be performed.

\section{Results}

Table 1 provides representative CAR's for the Delaware and nonDelaware portfolios for the seven decisions that we studied. The numbers in parentheses are $t$-statistics. The CAR's for the decision day and for two, four, and nine trading days later are provided in the table, since they should indicate the reactions of the securities markets within the very short run (within a day or two of the decision) and over a slightly longer run (within two weeks). It seenis unlikely that the securities markets would require nore than two weeks to digest and react to the implications of these decisions.

In no instance did we find statistically significant (at the 95-percent level of confidence) ${ }^{154}$ negative CAR's for the Delaware portfolios; only for Unocal at $t=4$ and $t=9$ did we find statistically significant positive CAR's. Indeed, the pattern of positive and negative CAR's for the Delaware portfolios appears to be randon.

As we noted above, much of "the market" that serves as the basis for computing the CAR's may be composed of Delaware companies. Consequently, an additional test focuses on the portfolios of non-Delaware companies and exammes whether they showed significant CAR's relative to the market or relative to the Delaware portfolio CAR's. Only for Unocal at $t=2$ and subsequent trading days do the non-Delaware portfolios show statistically significant CAR's. In this case, the non-Delaware CAR's show a positive return, but so do the Delaware CAR's, and the differences between them are not statistically significant. Further, if we ask generally about significant differences between the CAR's of the Delaware and non-Delaware portfolios (rather than just about the simple coniparison of each with the market), we find that only for Singer at $t=$ 9 and for Lynch $I I$ at $t=2$ and $t=4$ are there significant differences, ${ }^{155}$ and for $L y n c h I I$ this significant difference disappears by $t=9$.

Overall, then, the results of the direct market model tests do not support the proposition that investors viewed any of the studied decisions as either favorable or adverse to shareholders' interests.

154. That is, under a null hypothesis of no relationship, our results in all instances had a 5 percent or greater probability of occurring because of pure chance or randomness.

155. In Singer, the Delaware portfolio shows a significant negative CAR relative to the nonDelaware portfolio; in Lynch II, the Delaware portfolio shows a significant positive CAR. 


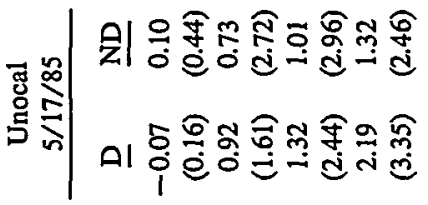

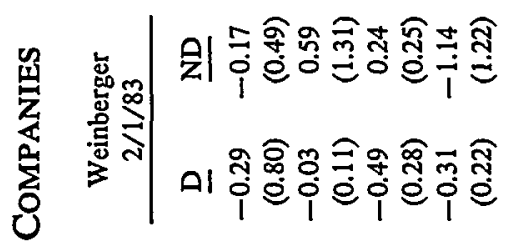

竞

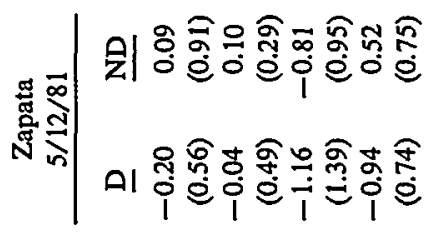

悹

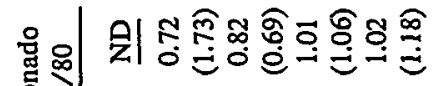

5

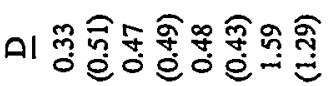

点

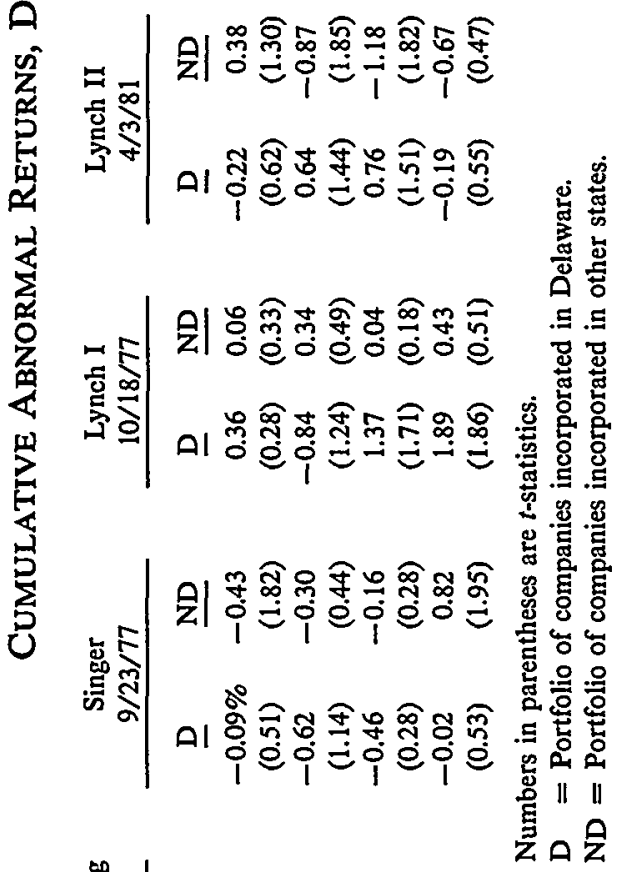

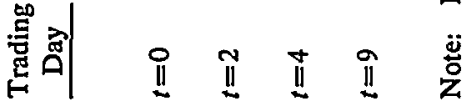




\section{Examination of Cumulative Abnormal Returns}

\section{Methodology}

As a further test of our original proposition, we examined the CAR's of the fifty individual companies in the Delaware portfolio during the days immediately following the Singer decision. ${ }^{156}$ If the consequences of Singer were adverse to shareholders' interests because takeovers would be discouraged, we would expect the shareholders of companies that would otherwise be more susceptible to takeovers to suffer relatively greater consequences-that is, those companies should show relatively large negative CAR's as a consequence of the decision. Conversely, if mvestors viewed Singer positively because it made exploitative cash-outs less likely, we would expect companies susceptible to takeovers to show relatively larger positive CAR's.

To test this more refined hypothesis, we identified a number of characteristics of companies that are likely to affect their susceptibility to takeovers. We then used the values of these characteristics for each of the fifty Delaware companies as the riglit hand (explanatory) variables in an ordinary least squares regression, in which the set of CAR's of the individual fifty Delaware compamies was the left hand (dependent) variable. ${ }^{157}$ We tlius tried to "explain" the relative sizes of the individual compaines' CAR's by the companies' other relevant characteristics.

We identified eiglit characteristics of companies that might, other things being equal, affect their susceptibility to being taken over: ${ }^{158}$

(1) Size. Smaller firms are more likely to be the targets for takeovers, since problems of financing the acquisitions are likely to be less serious.

(2) Recent growth. Growing firms may be more attractive to potential purchasers. ${ }^{159}$

156. Singer was the earliest of the decisions examined and thus afforded the best opportunity to gather the data necessary for our further test.

157. To correct for possible heteroscedasticity caused by the fact that the CAR's are themselves estimates with variances, we used the inverse of the estimated standard errors of the CAR's as weights in these regressions. For an explanation and justification of this procedure, see Saxonhouse, Estimated Parameters as Dependent Variables, 66 AM. ECON. REV., March 1976, at 178.

158. The characteristics were drawn from the possibilities discussed in Harris, Stewart \& Carleton, Financial Characteristics of Acquired Firms, in MERGERS AND ACQUISITIONS: CURRENT Problems IN Perspective 223, 231-32 (M. Keenan \& L. White, eds. 1982) and Wansley, Roenfeldt \& Cooley, Abnormal Returns from Merger Profiles, 18 J. FiN. \& QUANTITATIVE ANALYSIS, 149, 154 (1983); see also Hasbrouck, The Characteristics of Takeover Targets, $9 \mathrm{~J}$. BANkINg \& Fin. 351, 351-54 (1985); Knoeber, Golden Parachutes, Shark Repellents, and Hostile Tender Offers, 76 AM. EcON. REv., March 1986, at 155, 161-62 (discussing the characteristics of takeover targets as related to the likelihood that a firm will provide "golden parachutes" to managers).

159. But a lackluster growth record might indicate the potential for improvement to a knowledgeable prospective purchaser. 
(3) Profitability. Firms with greater profitability may be more attractive to potential purchasers. ${ }^{160}$

(4) Dividends relative to earnings. High dividends relative to earnings may indicate a large potential cash flow, which may be attractive to potential purchasers. ${ }^{161}$

(5) Price/earnings ratio. A low ratio of stock price to recent earnings may be indicative of a potential bargain for a prospective purchaser.

(6) Debt/equity ratio. A low debt/equity ratio should make a company more attractive to a prospective purchaser.

(7) Ratio of working capital to total assets. A high ratio of working capital to total assets is indicative of a high degree of liquidity, which should be attractive to a potential purchaser.

(8) Ratio of book value to market value. A high ratio of book value to market value may indicate that the stock is undervalued, and is thus a potential bargain for a prospective purchaser.

\section{Data and Specific Procedures}

The data for the eight characteristics were obtained largely from the COMPUSTAT files. ${ }^{162}$ The specific variables used were as follows:

(1) Size: Total coinpany assets at the end of the most recent company reporting year prior to the Singer decision. ${ }^{163}$

(2) Recent Growth: Average rate of growth in assets for the previous three years. ${ }^{164}$

(3) Profitability: Rate of return on stockholders' equity for the most recent reporting year.

(4) Dividends relative to earnings: The inverse of this ratio was used - that is, the ratio of earnings to dividends. ${ }^{165}$ The dividends and earnings figures used were both for the most recent reporting year.

(5) Price/earnings ratio: The inverse of this ratio was usedthat is, the ratio of earnings per share to the market price per share of common equity. ${ }^{166}$ The earnings figures used were for the most

160. The same caveat concerning growth applies to profitability. See supra note 159 .

161. Alternatively, a low ratio of dividends to earnings may suggest that a new management could make better use of available cash flow.

162. The COMPUSTAT files are a standard source of machine-readable data on balance sheet and profit-and-loss information for a large number of publicly traded companies.

163. We also tried company sales, with even less success.

164. We also tried growth in company sales.

165. By using the ratio of earnings to dividends, we could easily incorporate negative earnings (losses) without introducing severe distortions. This would not have been true if we had used the ratio of dividends to earnings.

166. The same justification that applies to the dividend/earnings ratio applies to the price/ earuings ratio. See supra note 165 . 
recent reporting year; the market price used was the price on the day before the Singer decision.

(6) Debt/equity ratio: The ratio of debt to equity for the company for the inost recent reporting year.

(7) Ratio of working capital to total assets: The ratio of working capital to total assets of the coinpany for the inost recent reporting year.

(8) Ratio of book value to market value: Book value was calculated as the value of stockholders' equity for the most recent reporting year. Market value was calculated as the product of the market price on the day before the decision times the number of shares of common equity outstanding.

\section{Results}

Table 2 shows the results of two ordinary least squares regressions, in which the Singer CAR's for the Delaware compames (as of $t=2$ and also as of $t=4$ ) are the dependent variable and the eight variables described above are the explanatory variables. ${ }^{167}$ Because the magnitudes of the coefficients in the regression are not important, we have just indicated the signs of the coefficients and their $t$-statistics. We have also indicated the signs that we would expect to find if Singer were adverse to the interests of shareholders. For example, a larger company would be less susceptible to a takeover and therefore should have experienced a sinaller negative CAR as a consequence of Singer; thus, under this hypothesis we would expect a positive coefficient for the assets variable in the ordinary least squares regressions. The other expected signs have coinparable explanations. If Singer were favorable to shareholders, the opposite signs would be expected to hold.

As can be seen im Table 2, only for the second equation, in which the set of Singer CAR's at $t=4$ is the dependent variable, are any of the explanatory variables statistically significant, and in that equation only two variables are statistically significant. Moreover, the significant negative sign on the growth variable is consistent with the hypothesis that Singer was adverse to shareholders' imterests, whereas the significant positive sign on the book value/market value variable is consistent with the hypothesis that Singer was favorable to shareholders' interests.

Accordingly, this additional evaluation of the Singer CAR's does not provide any support for the proposition that stockholders of Delaware companies considered Singer on balance to be either favorable or adverse to their interests.

167. Similar regressions for CAR's for other time periods yielded similarly non-significant results. 
TABLE 2

The Results of Two ORdinary Least SQuares

REgRESSIONS IN WHICH THE SINGER CARS ARE

THE DEPENDENT VARIABLE AND VARIOUS

COMPANY ChaRACTERISTICS ARE EXPLANATORY VARIABLES

Expected

sign of

variable's

effect if

Singer were

adverse to

shareholders'

Actual

Actual

Explanatory variable

interests*

sign, $t=2$

sign, $t=4$

Size (assets)

$+$

(1.94)

(1.57)

Recent growth of assets

Profitability (earnings/equity)

Dividends/earnings

$+$

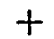

(0.66)

Stock price/earnings

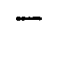

Debt/equity

$+$

Working capital/total assets

Book value/market value

$\tilde{\mathrm{R}}^{2}=0.24$

Note: Numbers in parentheses are $t$-statistics.

* If Singer were considered to be favorable to shareholders' interests, the expected sign would be reversed.

\section{III}

\section{ANALYSIS OF THE RESULTS}

The results of the standard market model tests and the more refined test involving the Singer CAR's present a conundrum, given the beliefs that market judgments generally are unbiased and that the market for corporate equities, in particular, reacts both rapidly and rationally to all significant new information. That is, given those expectations, what explaius the general absence of statistically significant market reactions (and even of consistent if not statistically significant patterns of reac- 
tions) to any of the seven apparently unanticipated, apparently significant Delaware court decisions we studied?

\section{A. Possible Explanations for the Results}

We identified four possible explanations for our results:

(1) The market model event study approach may not be an appropriate technique for evaluating the consequences of the seven decisions.

(2) Investors may have believed that courts in other states would follow the decisions of the Delaware courts relatively quickly. If so, investors would have reacted to the decisions as if they affected both Delaware and non-Delaware companies equally, making it impossible to isolate the decisions' effects on either Delaware or nonDelaware companies.

(3) Investors may have concluded that even though all seven decisions involve substantial changes in corporate governance rules, those changes will affect the behavior of a very small number of corporations. If so, investors could have rationally concluded that the decisions should not significantly change their valuation of the shares of Delaware companies.

(4) Investors may have concluded that the nature of judicial decisionmaking in corporate governance cases makes it unlikely that the rule or rules a court apphes in any given case will affect significantly the value of the stock of other companies ostensibly subject to those rules.

Each of these four explanations, on examination, appeared to have some inerit. In addition, as will become evident in the sections that follow, each of the four to some extent overlaps with one or more of the others. To avoid some of the complexity created by those overlaps, when we discuss the first three explanations we shall retain the assumption that the seven studied decisions involve significant doctrinal changes that have potential systematic implications-in short, that the seven decisions all were "events." When we discuss the fourth explanation, we shall reexamine that assumption. As will become clear, one who credits any of the four explanations also must conclude that the results of our study raise serious doubts about the premises on which Winter, Easterbrook, Fischel, and other contract-oriented coinmentators on corporate governance issues have based their work, and about most of the conclusions those scholars have reached on these issues. ${ }^{168}$

168. Our results also add to our skepticism about the merit of the extraordinary normative claim recently made by John Macey and endorsed by Fred McChesney, to the effect that absent dispositive data, courts should refrain from attempting to regulate innovative transactions that arguably involve unfair self-dealing or other misuse of corporate resources. See Macey, Takeover 


\section{The Limits of the Market Model}

Initially, we were skeptical about the first explanation, but we ultimately concluded that it may have some validity. Event studies have a long and largely successful history yielding significant and sensible results for many different kinds of events, including regulatory and legal decisions reached in other contexts. ${ }^{169}$ We could identify only two reasons why event study methodology might not be equally suitable to measure market reactions to the court decisions covered by our research.

The first was that investors might be uninterested in corporate governance rules or incapable of understanding how changes im those rules affect the value of investınents im corporate stock. Neither seemed likely, given both the overwhelming evidence of imvestor sensitivity to virtually any information that has miphications for securities values and the custoniary supposition that the inarket is the best unbiased mdicator of the economic significance of such information. However, we also noted that if one assumed that the inarket was significantly mefficient with regard to information concerning judicial decisions, one also would reject unequivocally Winter's thesis concerning how investors' decisions shape corporate law. If one assumed market mefficiency, then security prices wonld not provide an accurate indicator of shareholders' evaluations of and reactions to different states' laws, and hence would not influence systematically managers' decisions concerning where to incorporate.

A second possibility was that investors, as a group, were interested in and capable of evaluating the seven decisions we studied, but that most firms face only a remote possibility of becoming involved in transactions that would be affected by those decisions. ${ }^{170}$ Consequently, the decisions inay have only very small effects on market values, and event study methodology, as coinmonly practiced, may not be sufficiently powerful to detect such sinall effects. In essence, even if the effects are present and quantitatively important, they are drowned out by the (quantitatively larger) background noise of the capital markets. Therefore, no statistically significant effects are found.

In response to this second possibility, researchers using event study

Defense Tactics and Legal Scholarship: Market Forces Versus the Policymaker's Dilemma, 96 YALE L.J. 342 (1986); McChesney, Assumptions, Empirical Evidence and Social Science Method, 96 YALE L.J. 339 (1986). A more complete response to Macey and McChesney's arguments must await another day.

169. See studies cited supra note 64 .

170. All of the decisions that we studied other than Maldonado and Zapata relate directly or indirectly to takeover bids, which are made for relatively few firms. Maldonado and Zapata relate to shareholder derivative suits. One study found that, on average, a company will become involved in a class action or a derivative suit once every 17.5 years. Jones, An Empirical Examination of the Incidence of Shareholder Derivative and Class Action Lawsuits, 1971-1978, 60 B.U.L. REv. 306, 313 (I980). 
methodology to mvestigate the consequences of changes in corporate law might attempt to use samples comprised of firms that are supersensitive to the implications of those changes. For example, it has been suggested that during the early 1980's, oil companies might have been supersensitive to takeover bids. ${ }^{171}$ But while using supersensitive companies may have some merit, it also poses serious methodological risks. Use of a narrow sample creates the danger that the researcher may not be able to distinguish between the effects of the variables under consideration and effects caused by comcidental extraneous events. Or, even worse, the researcher might mistakenly attribute to the former the effects of the latter. For example, using a sample limited to oil companies raises the risk of confounding the effects on market values of changes in the price of oil with the effects of legal decisions.

If event study methodology is not powerful enough to detect the effects of significant changes im corporate law, the analytical framework used by many participants in the current corporate governance debate is subject to serious methodological question. To elaborate: If the likelihood of randomly selected Delaware compames' being involved in transactions that would be affected by any of the seven decisions-that is, takeovers or shareholder derivative suits-is so remote that even apparently major changes im Delaware law do not affect market values significantly, then serious doubts arise concerning the validity of claims made by contract-oriented commentators that the "market for corporate control" and the threat of derivative litigation serve as effective disciplinary influences on corporate managers.

\section{The Extraterritorial Effect of Delaware Court Decisions}

The second explanation we considered was that investors inight have been confldent that the courts of other states would follow the lead of the Delaware courts. This explanation, too, has some persuasive force. Ultimately, though, we do not behieve it provides a fully satisfactory explanation for our results.

Cary and Winter both hypothesize, albeit using different rationales, ${ }^{172}$ that competitive pressures will cause most states to adopt simi-

171. We are indebted to John Coffee for this suggestion. To some extent, we did structure our sample so as to include firms that were more sensitive to takeover possibilities. We restricted our sample to manufacturing and mining companies, so as to reduce the possibility that potential regulatory problems might affect the outcomes, and we excluded the largest manufacturing and mining firms because they might pose greater financing problems for a corporate raider. Also, by restricting our sample to manufacturing and mining companies, we increased the sensitivity of our second-stage test, because the different accounting conventions used by certain other industries could have clouded the possible effects of tests relating cumulative abnormal returns to variables calculated by using figures drawn from financial statements. In essence, Coffee's suggestion is that we should have been even more selective.

172. See supra note 20. 
lar corporate governance rules. Moreover, courts in other states often have looked to the Delaware courts' decisions for guidance, especially when the Delaware courts have dealt with an issue that non-Delaware courts have yet to resolve. ${ }^{173}$ But even state courts that tend to follow Delaware's lead are unlikely to follow every zig and zag of Delaware doctrine in an area, such as regulation of cash-out mergers, in which the Delaware courts have frequently changed their approach. ${ }^{174}$ In addition, adherence to Delaware precedent is far from universal. ${ }^{175}$ And in the case of Zapata, the Delaware courts clearly adopted a rule different from the one that the courts of several other states had einbraced. Consequently, we concluded that it was unrealistic to beheve that investors were confident that courts in inost other states would quickly follow all the Delaware decisions we studied. ${ }^{176}$

\section{The Decisions Will Affect Few Companies' Conduct}

The third explanation, that the changes in doctrine announced in the seven studied decisions will affect few coinpanies' conduct, also has soine explanatory force. Richard Epstein has suggested, in a related context, that the actual social and economic impact of courts' choices between coinpeting common law rules often is minimal. ${ }^{177} \mathrm{His}$ arguinent, in effect, is that while a court's choice of a rule (for example, whether to base hability in tort on negligence or on principles of strict liability) may change the outcome of a few marginal cases, in most cases subject to the rule the outcoine will be the same no inatter which of the competing rules the court chooses to apply. ${ }^{178}$ Epstein, however, also acknowledges that certain rules are likely to have significant effects, particularly "gatekeeper" rules governing when a party will have standing to sue, and rules that permit or prohibit large groups of transactions. ${ }^{179}$

Applying Epstenı's analysis to our studied decisions, one reasonably

173. See, e.g., Bove v. Community Hotel Corp., 105 R.I. 36, 249 A.2d 89 (1969).

174. In Coggins v. New England Patriots Football Club, 397 Mass. 525, 492 N.E.2d 1112 (1986) and Alpert v. 28 Williams St. Corp., 63 N.Y.2d 557, 473 N.E.2d 19, 483 N.Y.S.2d 667 (1984), state courts used a purpose test to evaluate cash-out mergers subsequent to the Delaware court's abandonment of that test in Weinberger.

175. See, e.g., Asarco, Inc. v. Court, 611 F. Supp. 468,478 (D.N.J. 1985) (holding New Jersey courts would not follow Delaware decisions approving issuance of classes of stock with unequal voting rights).

176. If all other states always conformed their corporate laws to those of Delaware, this outcome could imply either perfect collusion or perfect competition among the states in the "market for corporate law." However, the perfect competition hypothesis also would require the assumption that all companies' managers seek the same legal environment, contrary to the hypothesis advanced by Baysinger \& Butler, supra note 39, at 190-91. Assuming either perfect collusion or perfect competition seems unrealistic.

177. Epstein, The Social Consequences of Common Law Rules, 95 HARV. L. Rev. 1717 (1982).

178. Id. at 1725 .

179. Id. at 1721-22. 
could conclude that two of them-Lynch $I$ and Lynch $I I$-will change the outcome of relatively few cases and, more importantly, will affect managers' conduct in a relatively small number of instances. ${ }^{180}$ Lynch $I$ held that certain information, which a federal court had held might be found material as a matter of fact, was material as a matter of law. Thus, Lynch $I$ appeared to establisli disclosure obligations under Delaware law that are soinewhat more extensive than tliose establislied by federal law. ${ }^{181}$ While this loolding represented a sharp cliange in Delaware law, it did not significantly mcrease the disclosure obligations of the managers of publicly lield Delaware companies. Moreover, in very few cases is it likely that a Delaware court will liold to be material any information that a federal court would hold to be not material. ${ }^{182}$ Thus, given the federal disclosure obligations that existed prior to $L y n c h I$, investors miglit well liave concluded that the state law rule establislied by Lynch $I$ would have little impact on their future well-being.

Investors also miglit liave reached a similar conclusion about $L y n c h$ $I I$, though for different reasons. The key issue in Lynch II involved the weiglit to be given to the fact that between the date of the transaction at issue and tlie date at which damages were awarded, the value of TransOcean's principal asset, oil reserves, lad increased greatly because of events that neitlier Esmark nor TransOcean's public shareliolders reasonably could liave anticipated. Absent that increase in value and the court's decision that tle plaintiff class was entitled to sliare in it, Lynch II would be of limited precedential significance. Since cases involving questions of low to allocate windfalls comparable to the one in Lynch II will arise very infrequently, ${ }^{183}$ investors might liave concluded that Lynch II would have little effect on tlie value of tlieir investments in other companies. ${ }^{184}$

Comparable conclusions do not seein justified, though, witl regard to Singer, Weinberger, Maldonado, Zapata, or Unocal. All but Unocal deal, in whole or in part, witl gatekeeper issues of the sort Epstein identi-

180. Corporate managers usually consult lawyers before entering into major transactions. Thus, a change in corporate governance rules is likely to have more significance in terms of how it will influence the structure of future transactions than in terms of how it will affect the outcome of future litigated cases.

181. See supra text accompanying notes 88-93.

182. Different results are not likely because the standard of materiality adopted by the Delaware court is virtually identical to that used by federal courts. See Lynch I, 383 A.2d at 281 .

183. But see Coggins v. New England Patriots Football Club, Inc., 397 Mass. 525, 492 N.E.2d 1112 (1986) (judge valued each share at $\$ 80$ rather than the offered $\$ 15$; difference attributable largely to increased value of National Football League franchises).

184. While the analysis in the text might lead one to question the inclusion of Lynch $I$ and $L y n c h I I$ in our study, it should be recalled that $L y n c h I$ and $L y n c h I I$ were two of the four decisions that Fischel claimed would reduce the wealth of shareholders in Delaware corporations. See Fischel, supra note 25, at 934-35. 
fies as most likely to have significant impacts. ${ }^{185}$ All have been viewed by commentators as decisions that have significant imphications for the effectiveness of two of the principal structural constraints on managers' actions-takeover bids and shareholder derivative suits. In fact, it was because takeover bids play such an important role in many models of the corporate governance system that we added an analysis of Unocal to our study-as a sort of "acid test"- -after we found httle or no statistically significant investor reactions to the other six decisions. Moreover, their impact is likely to be palpable. Managers planning inergers, responses to takeover bids, and reviews of derivative claims almost always seek the advice of counsel and often try to operate close to the limits of what the law allows. ${ }^{186}$ Thus, Singer, Weinberger, Zapata, and Unocal are likely to influence not only the outcomes of future cases, but, more significantly, the way in which many transactions are structured. ${ }^{187}$

\section{The Indeterminacy of Courts' Doctrinal Statements}

We were left, then, with one potentially convincmg explanation: Investors do not believe that the Delaware courts' decisions in corporate governance cases-even cases viewed by virtually all commentators as doctrinally and practically significant-cause meaningful changes in the value of the stock of Delaware companies. Evaluatimg this explanation required that we reexamine the assumptions we had made concerning the process by which courts deal with corporate governance issues, as well as our characterizations of the seven decisions included in this study.

Corporate law's principal objective, as it relates to issues of corporate governance, is to structure the relationship between corporate shareholders and managers in a manner that facilitates the efficient operation

185. Singer reestablished the right of shareholders to challenge cash-out mergers on equitable grounds, a right that many observers believed the Delaware courts would no longer enforce. See supra note 86. Weinberger modified substantially the grounds on which shareholders could mount the kinds of challenges made available by Singer. The Maldonado and Zapata decisions made clear that shareholders in Delaware companies would be able to pursue derivative claims in circumstances in which the law in other states may allow special litigation committees to dismiss suits asserting meritorious claims. See Joy v. North, 692 F.2d 880, 888-92 (2d Cir. 1982) (discussing the apparent differences between the Delaware and New York rules), cert. denied, 460 U.S. 1051 (1983).

186. The impact of legal rules in these situations thus is likely to be considerably greater than in situations where human behavior appears to be predominantly governed by social mores. See generally, Ellickson, Of Coase and Cattle: Dispute Resolution Among Neighbors in Shasta County, 38 STAN. L. REv. 623 (1986) (case study of informal resolution of disputes over trespassing livestock in a rural area).

187. One who rejects our analysis on this point and adopts the view that the studied decisions will affect few future transactions will nonetheless come to a similar conclusion. That is, if almost no judicial decisions significantly affect shareholders' interests, serious questions arise as to whether shareholders exert much influence on the development of corporate law. And, absent the possibility of relying on market forces (exerted by shareholders) to shape corporate law, one has little choice but to make normative arguments concerning what corporate law should be. See infra text accompanying notes 206-11. 
of business enterprises. ${ }^{188}$ Most prior analyses of the systematic impact of corporate governance rules have been based on agency-cost theory and a quasi-contractual model of the corporation. ${ }^{189}$ Agency-cost theorists generally assume that managers will act to advance their personal interests whenever they can and that one major function of corporate governance rules is to constram managers from so acting. ${ }^{190}$ Many of those theorists view corporations as primarily contractual entities, or as a "nexus of contracts," and equate fiduciary obligations with generalized contractual provisions that managers and shareholders can use to resolve unanticipated future conflicts. Consistent with this view, these contractoriented commentators tend to construe courts' doctrinal statements as elaborations of the shareholder-manager "contract" designed to allow one to predict with considerable confidence how a court will resolve all future controversies imvolving transactions or issues similar to those mvolved im the cases $m$ which those doctrinal statements were made. ${ }^{191}$

Up to this point, our analysis has largely been consistent with the contract-oriented commentators' view of the world. But the results of our study, as well as our experience with the law, suggest that that view is inaccurate in several important respects. ${ }^{192}$ Transactions and cases frequently differ with regard to numerous factual characteristics that courts are likely to consider important. Consequently, knowing what the "law"

188. Some frame this objective in quasi-contractual terms-that the law's objective is to resolve disputes between shareholders and managers in the same manner as those parties would have resolved such disputes had they been anticipated at the time the corporation was formed and their resolution negotiated at arms' length. See, e.g., Easterbrook \& Fischel, supra note 23, at 702-03; see also supra note 5 . Of course, as with the statement that managers are fiduciaries, this definition "only begins analysis; it gives direction to further inquiry." SEC v. Chenery Corp., 318 U.S. 80, 8586 (1943). Left unanswered is the critical question: To what terms would the parties have agreed? Most agency-cost theorists base their answers to that question on the assumption that "[i]t is very difficult ... to limit the discretion of corporate management without impairing corporate efficiency." Winter, supra note 17, at 290. But there may be important differences between the bargains that shareholders and managers would have made, had they actually negotiated all elements of their relationship, and the bargains that economic analysts attribute to those "negotiations." See generally Leff, Economic Analysis of Law: Some Realism About Nominalism, 60 VA. L. REV. 451 (1974) (discussing danger that economic analysts will attribute to parties values that reflect those analysts' subjective preferences). Intangible and emotional factors also may be important in some investment decisions; such factors, however, frequently elude the grasp of economic analysts.

189. See, e.g., Baysinger \& Butler, supra note 39; Dodd \& Leftwich, supra note 30; Easterbrook \& Fischel, supra note 21; Easterbrook \& Fischel, supra note 23; Fisehel, supra note 25; Jensen \& Meckling, supra note 5; Winter, supra note 17.

190. This statement is accurate with regard to conflict of interest transactions, but is less clearly accepted with regard to transactions in which managers' interests coincide with the interests of shareholders. Compare Scott, Corporation Law and the American Law Institute Corporate Governance Project, 35 STAN. L. REV. 927 (1983), and Scott, The Role of Preconceptions in Policy Analysis in Law: A Response to Fischel and Bradley, 71 CORNELL L. REV. 299 (1986), with Fischel \& Bradley, The Role of Liability Rules and the Derivative Suit in Corporate Law: $A$ Theoretical and Empirical Analysis, 71 CORNELl L. REV. 261 (1986).

191. See supra text at note 24.

192. For thoughtful critiques of the model, see Clark, Agency Costs versus Fiduciary Duties, in 
is, in the sense of knowing that a court purported to rely on soine rule or rules to decide soine case or cases, frequently will not be sufficient to allow one to predict with a high degree of confidence how that court will deal with a new transaction. ${ }^{193}$

Particularly pertinent is Ohver Wendell Holmes' observation that "[t]he hife of the law has not been logic; it has been experience."194 If corporate law is to maintain an appropriate balance between the interests of shareholders and of inanagers, courts inust keep corporate governance rules flexible and fiduciary principles fluid. ${ }^{195}$ If the courts, in the interest of protectimg shareholders' rights, promulgate rules that allow any shareholder to challenge any transaction that arguably is adverse to his interests, soine shareholders surely will react by behaving strategically, bringing nuisance suits that will enable thein to enrich theinselves at the expense of the shareholder population as a whole. In addition, the threat of shareholder hitigation will deter soine inanagers from taking soine prudent business risks or engaging in soine potentially beneficial transactions with interested parties.

Similarly, if the courts announce that they will not review the substance of certam kinds of managerial decisions (for example, those made either by executives or by disinterested directors) so long as certain specified decisionmaking procedures have been followed, soine inanagers will react by making foohsh decisions ${ }^{196}$ while others will scrupulously follow

Principals and Agents: The Structure of Business 55 (J. Pratt \& R. Zeckhauser eds. 1985); Brudney, supra note 2.

Some commentators argue that managers' conduct is influenced more by internal constraints, such as responsiveness to social, legal, and ethical norms, and by informal constraints, such as concern about one's reputation in the community, than by legal strictures. See Arrow, The Economics of Agency, in PRINCIPALS AND AGents: The StRUCTURE of Business, supra, at 50; Eisenberg, New Modes of Discourse in the Corporate Law Literature, 52 Geo. WASH. L. REv. 582, 594 (1984). This observation probably has considerable merit, but it does not satisfactorily explain the absence of any meaningful investor reaction to apparent changes im corporate law.

193. Charles Yablon has authored two of the best discussions of the relationship between precedent and predictability in the law. See Yablon, The Indeterminacy of the Law: Critical Legal Studies and the Problem of Explanation, 6 CARDozo L. REv. 917 (1985) (arguing that the relationship between precedent and future court decisions is loose or indeterminate, but that some degree of systemic predictability nonetheless exists); Yablon, Law and Metaphysics (Book Review), 96 YALE L.J. 613, 635 (1987) ("In some way that we do not understand very well, lawyers [and judges] ... can use legal argument to change the responses that actors within the legal system deem 'appropriate' in connection with certain legal formulations."). If both parties to a legal dispute can predict the outcome, or even can agree on the probabilities of outcomes, they presumably will choose to settle rather than proceed to litigate fully their dispute. See Gould, The Economics of Legal Conflicts, 2 J. Legal Stud. 279 (1973); Preist \& Klein, The Selection of Disputes for Litigation, 13 J. LeGAL STUD. 1 (1984).

194. O.W. Holmes, THe Common LAW 1 (1881).

195. Many classic corporate law decisions deal with unique factual situations and are notable for the opacity of their doctrinal statements. See, e.g., Perlman v. Feldman, 219 F.2d 173 (2d Cir. 1955); Jones v. H.F. Ahmanson \& Co., 1 Cal. 3d 93, 460 P.2d 464, 81 Cal. Rptr. 592 (1969).

196. See, e.g., Kamin v. American Express, 86 Misc. 2d 809, 383 N.Y.S.2d 807 (Sup. Ct.), aff'd, 
the designated procedures im order to legitimate transactions in which they enrich themselves at shareholders' expense. ${ }^{197}$ This latter danger is particularly acute with respect to situations, such as those involved in the cases included in our study, in which managers regularly seek the advice of counsel before deciding how to proceed.

The history of the law of cash-out mergers provides a paradigm of the process by which courts develop corporate governance "rules."198 It also illustrates why investors rationally could have concluded that none of the four merger-related decisions included in our study would affect the value of the stock of Delaware companies generally.

Courts at one time allowed a single objecting shareholder to block a cash-out, without inquiring into whether the terins of the transaction were in any way unfair. Recognizing that such a rule allowed minority shareholders to frustrate the will of the majority and rarely advanced other legitimate purposes, state legislatures and state courts moved to permit a company's managers, with the concurrence of a majority (or super-majority) of the company's shareholders, to arrange a cash-out merger. The legislatures and courts did not, however, ignore the possibility that some cash-outs would be unfair. They dealt with that possibility by providing a dissatisfied shareholder with the right to seek a judicial determination of the value of his shares in an appraisal proceeding.

In theory, appraisal represented an acceptable technique for reconciling the potentially conflicting interests of managers, majority shareholders, and minority shareholders. In practice, however, it fell far short of that goal. The procedural complexity and the cost of seeking appraisal, combined with the courts' use of valuation methods that provided most dissenting shareholders with scant hope of obtaining satisfactory relief, made appraisal a "remedy of desperation." 199 To the extent that courts held that appraisal provided the only remedy available to a shareholder objecting to a cash-out, they opened the door to managers who sought to enrich themselves (or their principals) by arranging exploitative cash-out mergers.

Singer was decided very shortly after courts made it seem clear that shareholders objecting to arguably exploitative cash-outs were entitled to

54 A.D.2d 654, 387 N.Y.S.2d 993 (1976) (business judgment rule applied to directors' decision to forego $\$ 8$ million in potential tax benefits to avoid reducing reported earnings).

197. Certain extraordinarily generous executive compensation plans, keyed to factors that bear little relationship to executives' performance, are evidence of this phenomenon. Courts, in general, have been loathe to review the substance of these plans. See Vagts, Challenges to Executive Compensation: For the Markets or the Courts?, 8 J. CoRP. L. 231 (1983).

198. This history is described in Weiss, Historical Perspective, supra note 65, and Weiss, Balancing Interests, supra note 65 . The discussion in this article treats this body of law as having more continuity and consistency than is suggested by the discussions in those articles.

199. M. EISEnBERG, The Structure of THE CoRporation 83 (1976). 
no remedy other than appraisal under either federal or state law. ${ }^{200}$ Our earlier analysis of the potential significance of the Singer decision emphasized the "words" of the decision-the court's holdings concerning proper purpose and how fairness should be determined. But one could focus alternatively on the "music" of the decision-its philosophical tenor. Singer's music suggests that the Delaware Supreme Court was not hostile to cash-outs per se, but was committed to maintaining a reasonable balance between the interests of shareholders and managers of companies involved in cash-out mergers. An investor who was convinced that the words were much less important than the music would have predicted, with some confidence, that if implementation of Singer's holdings proved to be inconsistent with the court's philosophical objective, the court would modify those holdings. And that, in fact, is just what occurred.

The Delaware Supreme Court first interpreted Singer's holding concerning the purpose of a cash-out merger largely as establishing a pleading requirement that could easily be met by virtually any shareholder interested in actimg strategically to obstruct a cash-out merger. ${ }^{201}$ Then, in Weinberger, the court jettisoned Singer's holding concerning purpose. The court did not, however, revert to the rule that appraisal was a dissenting shareholder's exclusive remedy-a reversion that would have been inconsistent with the philosophy of Singer. Rather, it suggested that it would continue to allow shareholders to challenge cash-out mergers in class or derivative actions, but only if they could demonstrate that they had a substantial basis for claiming that those mergers were unfair.

Similarly, as the court began to emphasize that judgments concerning the fairness of cash-outs should be based on the process by which they were arranged and the adequacy of the prices bemg paid rather than on whether they were motivated by "proper purposes," the court also fleshed out what it ineant by "fair dealing" and gave inore content to the

200. While the shortcomings in the appraisal remedy had been known for some time before Singer was decided, the potential for exploitation became apparent only after the Supreme Court made clear that same year that no federal remedy was available in the case of unfair cash-outs. Santa Fe Industries, Inc. v. Green, 430 U.S. 462 (1977). In this regard, Singer illustrates a potential influence on the development of state doctrines of corporate law that is not often noted-the threat of federal intervention and the likelihood that Delaware's courts, in particular, will act to avert that threat. See Ferrara \& Steinberg, The Interplay Between State Corporation and Federal Securities Law-Santa Fe, Singer, Burks, Maldonado, Their Progeny and Beyond, 7 DEL. J. CoRP. L. 1, 7 (1982); Weiss, Balancing Interests, supra note 65, at 26-27.

201. Delaware decisions subsequent to Singer made clear that any shareholder who alleged simply that the purpose of a merger was "solely to cash out minority shareholders at an inadequate price"-a statement that arguably characterized accurately every cash-out merger-could be assured of obtaining a trial on the fairness of the merger price. See Roland Int'l Corp. v. Najjar, 407 A.2d 1032 (Del. 1979); id. at 1039 (Quillen, J., dissenting). 
concept of "fair price." Lynch I, Lynch II, and Weinberger all were part of that process.

What emerged was a body of law that, on the one hand, seemed reasonably well-designed to prevent exploitative cash-outs and, on the other, made clear that largely obstructive litigation would not be permitted. An investor who viewed these merger-related decisions as part of an ongoing process through which the Delaware Supreme Court was attempting to fine tune the balance between shareholders' and managers' interests in an area where maintaining that balance is inherently difficult would not have attached a great deal of importance to the twists and turns in the court's successive doctrinal statements concerning the factors that it would examine to determine whether any given cash-out merger was fair or unfair. ${ }^{202}$

Similar observations can be made about the other decisions included in our study. Consider, first, Zapata, which held that in certain cases the court slould apply its own business judgment when deciding whether to accept a litigation committee's recommendation to dismiss a derivative suit. Much has been made of the differences between the approach taken by the Delaware court in Zapata and the New York Court of Appeals' decision in Auerbach v. Bennett, ${ }^{203}$ which held that under New York law courts may not exercise their own business judgment and should linit themselves to determining whether the members of a litigation committee are disinterested and whether the committee followed appropriate procedures in investigating the inerits of the derivative claim it seeks to lave dismissed. The holdings of the two decisions-their "words"-differ substantially. Nonetlieless, it is entirely possible that the two courts are playing the same "music"-that they will reach similar results in cases where litigation committees move to disimss derivative suits involvmg substantially identical claims. ${ }^{204}$

202. Three recent decisions further illustrate the Delaware Supreme Court's approach to regulating cash-out mergers. Compare Weinberger v. UOP, Inc., 457 A.2d 701, 709 n.7 (1983) (discussing the benefit of having independent directors represent minority shareholders in a cashout) and Rosenblatt v. Getty Oil Co., 493 A.2d 929, 938 (Del. 1985) (emphasizing that independent directors' vigorous participation in the negotiation of a cash-out supports conclusion that its terms were fair) with Rabkin v. Philip A. Hunt Chem. Corp., 498 A.2d 1099, 1106 n.7 (Del. 1985) (cautioning against automatic assumption that participation by independent directors assures that cash-out terms are fair). From these decisions emerges a picture of a court that is concerned primarily about ensuring that mergers are substantively fair and that is justifiably cautious about open-endedly endorsing intracorporate procedures that managers may be able to manipulate to create a facade of procedural fairness for transactions that are substantively exploitative.

203. 47 N.Y.2d 619, 393 N.E.2d 994, 419 N.Y.S.2d 920 (1979).

204. In cases where a shareholder-plaintiff is required to make a demand on a company's board of directors before proceeding with a derivative suit, the holdings of the Delaware and New York decisions are very similar. See Aronson v. Lewis, 473 A.2d 805 (Del. 1984) (holding that demand may be excused only where facts are alleged with sufficient particularity to create a reasonable doubt about whether the directors' actions were entitled to the protections of the business judgment rule). 
Consider, for example, a situation involving these facts: (1) a shareholder has filed a derivative suit alleging "garden variety" self-dealing by a majority of a company's directors; (2) substantial evidence supports the shareholder's claim; and (3) after investigating the claim, a special litigation committee has moved to have the derivative suit dismissed. Applying Delaware law, a court could deny the committee's motion on one of three grounds: (1) that the hitigation committee's members had not established their independence; (2) that the committee had not properly investigated the merits of the derivative claim; or (3) that, in the court's business judgment, the derivative claim should not be dismissed. Applying New York law, a court would be limited to the first two of these grounds. However, the mability of a court applying New York law to make its own business judgment does not necessarily lead to a result contrary to the result that a Delaware court would reach. Instead, it imght well lead the court to view more skeptically the committee's claims that its inembers were independent and that its investigation had been reasonable. ${ }^{205}$ "Independent directors" and "reasonable investigation," after all, denote malleable concepts, not scientific formulas etched in stone.

We are not asserting that the two states' courts are certain to reach similar results in cases involving similar claims or that reasonable arguments cannot be made that one court's approach is better (or worse) than the other's. We are suggestimg, however, that how one views these (and other courts') litigation committee cases involves a question of perspective. If one views the central issue in these cases as the extent to which courts should defer to litigation committees' recommendations (or to business decisions made by ostensibly disinterested directors), the different doctrinal statements of the Delaware and New York courts probably signal the likelihood of different outcomes. But if one views both the Delaware and New York courts as primarily concerned with the persistently troublesome problem of how best to dispose of non-meritorious derivative claims that cannot easily be dealt with using customary summary procedures, ${ }^{206}$ different outcomes do not seem inevitable. ${ }^{207}$ That is, investors quite rationally could have concluded that the seemingly dis-

205. See Parkoff v. General Tel. \& Elecs. Corp., 53 N.Y.2d 412, 425 N.E.2d 820, 442 N.Y.S.2d 432 (1981); Rosen v. Bernard, 108 A.D.2d 906, 485 N.Y.S.2d 791 (App. Div. 1985).

206. Claims of this sort are often described as "strike suits," in that their settlement value often far exceeds their intrinsic merit. See Blue Chip Stamps v. Manor Drug Stores, 421 U.S. 723, 740 (1975).

207. This conclusion is supported, by analogy, by the Delaware courts' decisions concerning defensive tactics. Unocal indicated that managers' decisions concerning how to respond to unsolicited takeover bids would, in general, be evaluated within the rubric of the business judgment rule. Subsequent decisions have made clear, though, that the courts can and will review decisions to employ defensive tactics much more closely than they do managers' more ordinary business decisions. A federal court applying New York law has adopted a similar approach. See Hanson Trust PLC v. ML SCM Acquisition Inc., 781 F.2d 264, 285 (2d Cir. 1986) (Oakes, J., concurring, 
parate approaches the Delaware and New York courts were taking to reviewing the actions of litigation committees probably would not affect those courts' willingness to enforce managers' fiduciary duties, to defer to managers' business decisions in appropriate circumstances, or to deal summarily with shareholder claims they viewed as frivolous. Consequently, investors probably would not alter significantly the value they placed on the stocks of companies incorporated in either of those states. ${ }^{208}$

The vahidity of this perspective is supported by an examination of Unocal and related decisions. In the years prior to Unocal, the Delaware courts' opinions concerning managers' responses to uninvited takeover bids were "somethmg less than a seamless web."209 One common view of Unocal, as noted, was that it represented a decisive shift by the Delaware courts in favor of allowing managers more flexibility to resist takeover bids. Subsequent decisions, however, suggest that this characterization of Unocal was inaccurate or, at least, incomplete.

Unocal and a number of other decisions have allowed inanagers of Delaware corporations considerable latitude to implement new defensive strategies designed to counter the increasingly aggressive tactics being employed by firms making takeover bids. ${ }^{210}$ But a related line of decisions has made it clear that the Delaware courts are not giving managers

notes that same result could more easily be reached under Delaware law). See also infra notes 20911 and accompanying text.

In addition, Delaware decisions concerning the "independence" of directors on special litigation committees may be indicative of the approach courts applying New York law will follow. See, e.g., Hasan v. Clevetrust Realty Investors, Inc., 729 F.2d 372 (6th Cir. 1984) (holding both Delaware and New York law require similar inquiries concerning directors' independence); Lewis v. Fuqua, 502 A.2d 962 (Del. Ch. 1985). In most other respects, we note, New York and Delaware corporate law is quite similar.

208. To illustrate further the complexity of making judgments as to whether a given decision advances managers' or shareholders' interests, consider the possibility that the New York courts' approach, which appears to favor managers, could have exactly the opposite effect. If New York courts begin to employ more stringent standards to determine whether litigation committee members are "disinterested," they also may use those standards in other contexts and thus make it more difficult for managers of New York corporations to insulate interested party transactions from close judicial scrutiny by having them approved in advance by ostensibly "disinterested" directors. On the other hand, investors could share Professor Coffee's well reasoned if counterintuitive belicf that both the Delaware and New York rules will have the effect of increasing the number of strike suits instituted by plaintiff' lawyers. See Coffee, Understanding the Plaintiff's Attorney: The Implications of Economic Theory for Private Enforcement of Law Through Class and Derivative Actions, 86 ColUM. L. REv. 669, 720-24 (1986) (high costs and delays attendant on the litigation committee process encourage corporations to settle, making strike suits attractive to entrepreneurial lawyers).

209. Treadway Cos., Inc. v. Care Corp., 638 F.2d 357, 382 (2d Cir. 1980) (noting, also, that the Delaware courts' decisions "are not easily reconciled.") For an explanation of why courts' decisions in this area tend to be inconsistent, see Gilson, A Structural Approach to Corporations: The Case Against Defensive Tactics in Tender Offers, 33 STAN. L. REv. 819, 824-31 (1981).

210. In Unocal, the court justified its decision in large part by characterizing Mesa's bid as "a grossly inadequate and coercive two-tier front-end loaded tender offer." Unocal, [1984-1985 Transfer Binder] Fed. Sec. L. Rep. (CCH) I 92,046, at 92,211 (Del. May 17, 1985). 
carte blanche. Operating within the rubric of the business judgment rule, the Delaware courts, in cases decided subsequent to Unocal, have scrutinized rather intensively managers' efforts to oppose takeover bids and have held some of those efforts to be inappropriate. ${ }^{211}$ Consequently, while investors might reasonably have questioned the result the court reached in Unocal itself, they would not have had to be extraordinarily prescient to have made the judgment that Unocal did not signal a dramatic shift in the Delaware court's attitude. Rather, they could reasonably have interpreted Unocal as being entirely consistent with the Delaware court's long-standing if seemingly unprincipled tradition of allowing managers to employ defensive tactics in circumstances where the court considers those tactics to be reasonable and of rebuffing managers' efforts to use the same or other defensive tactics in circumstances where the court believes that they impinge unduly on shareholders' legitinate interests.

\section{B. Research Conclusions}

Our conclusion, in essence, is that the decisions we studied do not represent "events" because the doctrinal changes that the courts announced in those decisions do not foreshadow predictable differences in the outcomes of substantial numbers of future corporate governance cases. Rather, those decisions can best be viewed as parts of a process by which the Delaware courts continually attempt to fine tune the techniques they use to resolve disputes involving persistently troublesoine issues of corporate governance.

Soine might argue that this conclusion casts doubt upon our einpirical results, claiming that if none of the decisions we studied-indeed, virtually no reasonably foreseeable court decision in a corporate governance case-properly can be viewed as an "event," it would seein to follow that event study methodology is not an appropriate techinque for evaluating courts' decisions in such cases. That argument, however, is circular-it fails to distinguish between cause and effect.

The results of our study are significant precisely because they show that investors do not view the Delaware courts' decisions as "events." If one believes, as we do, that the market generally provides the best unbiased indication of the significance of new information, then event study methodology provides an appropriate techinque for evaluating corporate

211. See Revlon, Inc. v. MacAndrews \& Forbes Holdings, Inc., 506 A.2d 173 (Del. 1986); Packer v. Yampol, 54 U.S.L.W. 2582 (Del. Ch. April 18, 1986) (holding directors who authorized issuance of high-vote preferred stock were not disinterested); $c f$. Smith v. Van Gorkom, 488 A.2d 858 (Del. 1985) (decision approving sale of company to unrelated party was not protected by business judgment rule). In some respects, the Delaware courts appear to be embracing a proauction philosophy. See Gilson, supra note 209; Gilson, Seeking Competitive Bids Versus Pure Passivity in Tender Offer Defense, 35 STAN. L. REV. 51 (1982). 
governance decisions. Investors' apparent conclusion that none of the seven studied decisions justified significant changes in the market value of the stock of Delaware companies is an indication not of investors' inability to assess the importance of these decisions but of investors' insight into how the Delaware courts operate. Investors attribute little significance to those decisions, and stock prices remain relatively unchanged, because investors appreciate that the decisions do not foreshadow predictable differences in the outcome of future cases, since virtually all such cases will involve transactions that are potentially distinguishable from the cases that the Delaware courts have decided.

\section{IV}

\section{IMPLICATIONS OF THE RESULTS}

Our empirical results and our views of the market and of the courts' decisions provide several new insights. Some concern the long-standing controversy about the role that competition between the states plays in shaping the development of corporate law in the United States. Our results, like those of predecessor studies, tell us little about whether the corporate laws of Delaware or of other states strike an optimal balance between the interests of inanagers and of shareholders. But if investors do not find judicially-wrought changes in corporate law to be significant, we believe it is unhikely that investors consider differences between the corporate laws of different states to be inuch more inportant. ${ }^{212}$ Thus, $^{2}$ investors' well-documented failure to react to announcements of reincorporation decisions, like their failure to react to the judicial decisions we studied, may well reflect hittle more than their judgments about the indeterminacy of corporate law. This observation provides no direct support for Cary's argument that coinpetition among the states repre-

212. As noted previousiy, most state law provisions involve both potential costs and potential benefits for shareholders. See supra note 37. In addition, in recent years state legislatures havc tended to adopt relatively uniform statutes designed largely to facilitate corporate transactions; they have left to the courts the task of protecting shareholders' interests through imposition on managers of appropriate fiduciary obligations. See N.J. STAT. ANN. § 14A, at xi (West 1969). Thus, with one possible set of exceptions, differences between state statutes are not likely to be significant. The exceptions relate to statutes passed by several states to protect domestic corporations from hostilc takeover bids. See, e.g., Dynamics Corp. of America v. CTS Corp., 794 F.2d 250 (7th Cir.), cert. granted, 107 S. Ct. 258 (1986) (holding Indiana Control Share Acquisition Act, Ind. Code $\$ \$ 23-1$ to 42-1 unconstitutional). More recent examples are statutes designed to provide managers of domestic corporations with added insulation from potential liability in shareholder derivative suits. See, e.g., S. 533, 133d Del. Gen. Assembly $\S 2$ (1986) (to be codified at 8 DEL. CoDE ANN. $\S 102(b)(7)$ ). For a discussion of the new Delaware statute, see Veasey, Finkelstein \& Bigler, Delaware Supports Directors with a Three-legged Stool of Limited Liability, Indemnification, and Insurance, 42 Bus. LAw. 399 (1987). Investors conceivably could view these new statutes as economically significant. On the other hand, Roberta Romano conducted event studies of market reactions to several different kinds of anti-takeover statutes and found no statistically significant results. Romano, supra note 48. 
sents a race for the bottom. ${ }^{213}$ But it does cast considerable doubt on Winter's claim that investors' decisions concerning whether to buy the stock of Delaware or non-Delaware companies operate so as to preclude the developinent of unduly pro-inanager systems of corporate law. ${ }^{214}$ Given the results of our study, those interested in continuing to debate the differences between states' corporate laws or the pros and cons of federal involvement in corporate governance issues must, we believe, focus primarily on the normative, historical, and institutional factors involved. $^{215}$ In fact, if not in theory, there is little evidence that there exists an investor-dominated "market for corporate law."216

Our study also has several implications for the work of cominentators who analyze courts' decisions in corporate governance cases either in terms of the relationship between those decisions and investors' "contractual" expectations or in terms of the systematic effects those decisions will have on the wealth of shareholders in other corporations. Investors, as einbodied in "the market," seem to consider the Delaware courts' decisions to be inconsequential as regards shareholders' wealth and, by imphication, largely mdeterminate of the outcome of future cases.

213. A relevant consideration remains whether state corporate laws impose too few constraints on managers and thus "tend to sap the public's confidence, and therefore willingness to participate, in capital markets." Eisenberg, Corporate Legitimacy, Conduct, and Governance-Two Models of the Corporation, 17 CRE1Ghton L. REV. I, 16 (1983).

214. In addition, the fact that managers of many corporations have continued to propose antitakeover measures that numerous studies have found result in statistically significant reductions in shareholder wealth leads us to doubt whether a great deal of credence should be given to the argument that managers always are sensitive to developments that will result in a decline in stock prices. Many managers' conduct in this regard suggests they are more concerned with their shortterm well-being than with the prospect that changes in corporate governance rules may lead to a decrease in stock prices. We find unconvincing arguments to the effect that managers' self-interest is likely to predominate only in the takeover context. See Winter, supra note 17, at 287-89. Why selfinterest will not predominate in other contexts has not been explained satisfactorily.

215. This observation also is pertinent to the current debate about stock exchange and NASDAQ listing standards relating to the voting rights associated with publicly-traded stock. One member of the Securities and Exchange Commission has remarked that it is "precisely contrary to generally accepted economic theories" to believe that the exchanges are engaged in a "race to the bottom" when they abandon or decline to impose requirements that common stock have equal voting rights. Dual Class Capitalization: Solutions in Search of a Problem (remarks of Charles C. Cox, Commissioner, Securities and Exchange Commission, to the New York Stock Exchange Legal Advisory Committee (Dec. 19, 1986)) (on file with the California Law Review).

216. There may be, as Cary suggests, a manager-dominated "market for corporate law" in which managers choose what state's law will govern their firm, subject to the constraint, suggested by Winter, that managers cannot choose a state whose corporate law imposes net costs on shareholders. Viewed in this light, managers' decisions to reincorporate their firms in Delaware may represent Pareto improvements. See supra note 38. But those decisions only represent Pareto improvements as compared to decisions to remain incorporated in other states, not as compared to decisions to operate under a federal corporation law or federal minimum standards similar to those suggested by Cary. Since no federal corporation law or federal minimum standards exist, there is no way to measure empirically whether investors would prefer such laws or standards to the corporate laws of Delaware or other states. 
The market's reactions thus cast serious doubts on the utility, as an analytic construct, of the idea that corporations should be viewed as a "nexus of contracts." Whatever theoretical elegance this construct may have, it makes little sense to talk about shareholders' contractual (or quasi-contractual) rights if, as the market's reactions indicate, neither the content of those "rights" nor the transactions to which they apply is objectively ascertainable. Moreover, with regard to shareholders' wealth, the market's reactions clearly provide no support for the claims, made by Fischel and others, that several of the Delaware court decisions included in our study will have systematic effects that will reduce the wealth of shareholders of Delaware corporations.

Our analysis suggests that the market's failure to react to the seven decisions we studied is grounded in a sophisticated understanding of how courts' decisions actually do affect shareholders' wealth. Contract-oriented commentators have tended to discuss corporate law and judicial decisions as if they were one-dimensional rather than multidimensional-as if a court's doctrinal statements in one case, and those doctrinal statements alone, will deterinme the outcome of all future cases involving similar transactions or similar decisions. Rarely will that be so. The courts, on occasion, announce unambiguous rules that appear to govern all future controversies imvolving certain categories of transactions or managers' decisions. But, as we have noted, those rules often either create opportunities for unconstructive shareholder litigation ${ }^{217}$ or provide managers with "roadmaps for fraud."218

To avoid these hazards, courts customarily rely on a combination of techniques. First, they regularly include malleable terms-such as "independent directors," "good faith inquiry," "reasonable basis," and "fair dealing" - within their doctrinal fornulations. The flexibility of these terms, as applied to particular sets of facts, opens up the possibility that in future cases the courts will reach results that established doctrines, at first blush, might appear to preclude. ${ }^{219}$

Second, courts frame their decisions in terms that allow several different decision rules to be at least arguably relevant to the facts of most foreseeable future cases. They do this because they recognize: (1) that a doctrinal approach that focuses on the process by which a challenged decision was reached-for example, whether it was approved by "independent directors"-will have a different impact on future corpo-

217. This was the case with the Singer purpose test. See supra note 201.

218. This was the case with the pre-Singer rule holding that shareholders objecting to cash-out mergers were limited to seeking judicial appraisals of their shares. See supra text accompanying notes 79-80; see also supra note 197 and accompanying text.

219. Note that we speak of "opportunities" that courts have to reach such results, not of certainties that they will do so. 
rate conduct than an approach that focuses on whether the substance of the challenged decision was "fair" and "reasonable;" and (2) that any doctrinal approach designed to prevent managerial misbehavior will provide shareholders with some opportunities to act strategically, while any approach designed to preclude strategic shareholder behavior will provide managers with some opportunities to enrich themselves improperly. ${ }^{220}$

Consequently, the courts have created a situation in which, when dealing with lawsuits involving challenges to corporate transactions, they typically will be able to base their decisions either on whether the relevant statutory rules have been compled with or on whether the relevant fiduciary obligations have been met. If a court chooses the latter option, it will have the option either to focus exclusively on the decisiouniaking process used or to evaluate the substantive merit of the challenged transaction as well. Hence, in any given case a court probably will be able to use soine arguably relevant case law precedent to hold that one or more of the following considerations is either relevant or dispositive:

(1) that a company did or did not comply with relevant statutory formalities;

(2) that the person or persons who approved the transactions at issue held or lacked the authority to do so;

(3) that the relevant corporate decisionmakers were or were not "disinterested" or "independent;"

(4) that those decisionmakers made "reasonable inquiries" or "all appropriate inquiries" before acting;

(5) that all material information was or was not provided to the disinterested directors or shareholders who approved the challenged transaction; and

(6) that the terms of the challenged transaction were or were not "reasonable" or "fair."

This is not to suggest that the "rules" courts apply to decide cases involving corporate governance issues do not have normative and institutional implications, or that lawyers and law professors should not atteinpt to analyze those iniplications. ${ }^{221}$ But when lawyers and law

220. Kenneth Davis has advanced a complementary framework for evaluating the decision rules courts use to review the actions of corporate fiduciaries. Davis, Judicial Review of Fiduciary Decisionmaking-Some Theoretical Perspectives, 80 Nw. U.L. REv. 1 (1985). Davis suggests that analysis should focus on the trade-off between the possibility that a rule will lead courts to uphold opportunistic decisions ("Type I Errors") and the possibility that a rule will lead courts to invalidate good faith decisions ("Type II Errors").

221. For example, the court suggested in Weinberger that it would attach considerable importance to whether a cash-out merger had been negotiated by a committee of disinterested directors. The court's suggestion undoubtedly will lead many companies to create such committees when they arrange cash-outs. This possibility raises a number of important issues for discussion: 
professors engage in such analysis they should take account of the most significant finding of our study: The market appears to view courts' statements that certain rules govern certain cases as components of a legal system that, im operation, succeeds in maintaining a rather stable balance between shareholders' interests and managers' prerogatives. True, courts sometimes modify rules that constitute seemingly important components of that system, and true, sometimes those modifications affect the efficiency with which the system operates. But rarely if ever do the courts alter substantially-that is, enough to cause investors to react-the system's fundamental equilibrium.

Even when a court announces a decision that appears to upset radically the existing balance between shareholders and managers, as arguably was the case with regard to most if not all of the decisions we studied, it seems clear that one should question whether the system's fundamental balance really has been altered. Most of the time, it seems safe to predict, the courts will retreat from the more extreme implications of what they have said. Consider, for example, the Delaware Supreme Court's decision legitimizing adoption of "poison pills," which several commentators predicted would provide managers with impregnable defenses against unwelcome takeover bids. ${ }^{222}$ In subsequent cases, the courts have scrutinized rather closely-much more so than their previous doctrinal statements suggested-the propriety of managers' decisions to employ these new devices. ${ }^{223}$ The conventional wisdom now is that poison pills represent largely ineffective takeover defenses. ${ }^{224}$

(1) whether disinterested directors are likely to represent effectively the interests of a corporation's public shareholders in such situations; (2) when directors should be considered "disinterested"; (3) how closely courts should review the decisionmaking procedures such directors have used; and (4) whether courts should defer to the substantive decisions such directors have made to the same degree that they defer to decisions made by directors about less important transactions with respect to which the directors are less likely to have competing loyalties. One should also consider, as part of such an analysis, one implication of our results-investors apparently do not believe that use of such committees will change materially the incidence of unfair cash-out mergers.

222. Moran v. Household Int'l Inc., 500 A.2d 1346 (Del. 1985). We explain in note 75, supra, why we did not include Moran in our study.

223. See supra note 211; Dynamics Corp. of America v. CTS Corp., 805 F.2d 705 (7th Cir. 1986) (remanding decision allowing activation of revised poison pill for further eonsideration); Dynamics Corp. of America v. CTS Corp., 637 F. Supp. 406 (N.D. Ill.) (enjoining aetivation of poison pill), aff'd, 794 F.2d 250 (7th Cir. 1986); Minstar Acquiring Corp. v. AMF Inc., 621 F. Supp. 1252 (S.D.N.Y. 1985) (enjoining activation of poison pill); Unilever Acquisition Corp. v. Richardson-Vicks, Inc., 618 F. Supp. 407 (S.D.N.Y. 1985) (enjoining issuance of preferred stock that lost 80 percent of its voting power when transferred); cf. Moran, 500 A.2d at 1354 (indicating court would limit circumstances in which poison pills properly could be employed). But see Gelco Corp. v. Coniston Partners, [1986 Transfer Binder] Fed. Sec. L. Rep. (CCH) ף 93,067 (D. Minn. Nov. 10, 1986) (upholding use of poison pill to defeat tender offer where price bid was less than breakup value of target company).

224. See, e.g., Greenhouse, Jurists Set Limits on Corporate Defenses, N.Y. Times, Dec. 29, 1986, at D5, col. 1; Miller, Lucky to Redeem 'Poison Pill' Rights In Proposed Settlement of Holder Suits, Wall St. J., Dec. 12, 1986, at 4, col. 1. 
In fact, given the oscillating nature of judicial decisionmaking in this area, the number of competing principles that arguably apply to any given corporate governance case, and the consequently indeterminate character of courts' doctrinal statements in such cases, the argument that the courts' decisions are most appropriately analyzed in terns of their potential systematic effects seems almost silly. Intuition, analysis of how courts behave, and the empirical infornnation produced by our study all strongly suggest that rarely if ever will a decision in some particular case trigger significant changes in the diligence or loyalty with which corporate managers, in general, carry out their functions. Investors, realizing this, do not react to the courts' decisions by changing significantly the value they place on the stocks of the compamies that, some theorize, will be affected by those decisions.

In this sense, investors evidently appreciate the strength of the corporate governance system, which hes in its stability. The system's weakness is that its complexity and uncertainty increase transaction costs. ${ }^{225}$ Increased complexity and uncertainty probably are unavoidable, though, for the courts are being asked to pass on the propriety of increasing numbers of transactions structured to test the limits of what the law allows. Even one who accepts the theoretical validity of the view that the corporate governance system in general, and fiduciary principles im particular, serves to implement "bargains" struck between managers and shareholders must concede that these "bargains" were indeterminate at the time they were made, and that consequently no other set of judicial responses reasonably can be anticipated.

225. This factor also makes life considerably more difficult for corporate practitioners. See Gruson, Tiny Delaware's Corporate Clout, N.Y. Times, June 1, 1986, at F6, col. 1 (reporting complaints of corporate counsel about perceived inconsistencies in Delaware Supreme Court's recent decisions in merger-related cases). And it makes life considerably more interesting for corporate law professors. However, whether the system's fundamental equilibrium is prejudicial to shareholders' interests and thus leads to less than optimal levels of investment in corporate stock cannot be determined empirically. See supra note 216. 
